\title{
Using Model-Based Systems Engineering to Provide Artifacts for NASA Project Life-cycle and Technical Reviews
}

\author{
Edith L. Parrott ${ }^{*}$ and Karen J. Weiland, Ph.D. ${ }^{\dagger}$ \\ National Aeronautics and Space Administration, Cleveland, Ohio 44135
}

\begin{abstract}
The ability of systems engineers to use model-based systems engineering (MBSE) to generate self-consistent, up-to-date systems engineering products for project life-cycle and technical reviews is an important aspect for the continued and accelerated acceptance of MBSE. Currently, many review products are generated using labor-intensive, error-prone approaches based on documents, spreadsheets, and chart sets; a promised benefit of MBSE is that users will experience reductions in inconsistencies and errors. This work examines features of SysML that can be used to generate systems engineering products. Model elements, relationships, tables, and diagrams are identified for a large number of the typical systems engineering artifacts. A SysML system model can contain and generate most systems engineering products to a significant extent and this paper provides a guide on how to use MBSE to generate products for project life-cycle and technical reviews. The use of MBSE can reduce the schedule impact usually experienced for review preparation, as in many cases the review products can be auto-generated directly from the system model. These approaches are useful to systems engineers, project managers, review board members, and other key project stakeholders.
\end{abstract}

\section{Introduction}

The institutional requirements for how NASA performs systems engineering are in the NASA Procedural Requirements (NPR) 7123.1, "NASA Systems Engineering Processes and Requirements". ${ }^{1}$ The NPR defines a set of required systems engineering products for program and project life-cycle and technical reviews. It also describes the 17 common technical processes for space flight, research and technology, and institutional programs and projects. These processes, which are used throughout all life-cycle phases, form what is called the NASA "systems engineering engine". The NPR describes typical best practices, with inputs, activities, and outputs, for each process. The NPR also contains the roles and responsibilities for implementing the requirements and processes, guidance on tailoring and customization of requirements and processes, activities and requirements for contractor oversight, and life-cycle and technical review requirements. Supplementary information on all these topics is available in the "Expanded Guidance for NASA Systems Engineering, Volume 1 and Volume 2." ${ }^{2,3}$ To date, NASA systems engineers have used primarily a document-centric approach to producing systems engineering artifacts and deliverables, although the NPR does not explicitly require this.

Currently, many systems engineers produce artifacts in the form of electronic records using office productivity software. The records are comprised of electronic documents, workbooks, diagrams, and chart sets. Since the contents of the electronic records are not related together in an organized fashion, several immediate and long-term problems can arise. Because each record is developed independently, the collection of records often contains inconsistencies in the detailed contents, despite intentional effort to find and correct errors. Identifying inconsistencies, determining all the affected electronic records, processing change requests to approve corrections, and making the updates are laborintensive. System-level queries and analyses are also labor-intensive as manual effort is often needed to synthesize the information residing in a multitude of unrelated sources and dissimilar formats.

The systems engineering community is moving toward a model-based approach that offers many benefits, including eliminating inconsistencies. Models can be descriptive of the system or used to analyze its performance. This paper primarily discusses the descriptive modeling aspects. There are multiple tools, languages, and methods that can be employed to create models; this paper focuses on the application of SysML.

\footnotetext{
* Systems Engineer, NASA Glenn Research Center, 21000 Brookpark Rd/162-2; edith.parrott@nasa.gov

${ }^{\dagger}$ Systems Engineer, NASA Glenn Research Center, 21000 Brookpark Rd/162-5; karen.j.weiland@nasa.gov
} 
Over the past decade, NASA has investigated model-based systems engineering (MBSE) and the Systems Modeling Language (SysML) ${ }^{4}$ through exploratory usage, training, and working groups. Hundreds of systems engineers have been trained in the language and tools, and some projects are using MBSE; however there is not yet widespread use of MBSE. After receiving training, engineers are often unsure of how to apply it to their projects, and how MBSE fits within the NASA systems engineering processes. The NPR neither mentions nor prohibits the use of MBSE. The recently issued expanded guidance supplement to the NASA Systems Engineering Handbook, Volume $2^{3}$ contains a section of introductory material about MBSE and efforts are underway as part of a MBSE Pathfinder to develop and evaluate how to use MBSE within the NASA systems engineering processes. ${ }^{5}$

A previous MBSE effort related to the NPR was the modeling performed by the Agency-level Systems Engineering Working Group, the NASA Langley Research Center, and the NASA Integrated Model-Centric Architecture teams. This effort modeled the 17 systems engineering processes themselves, with the internal inputs and outputs, to find inconsistencies within the NPR and have them corrected for a future revision.

This paper provides a guide and some examples of how to use MBSE, specifically with SysML, to produce the primary systems engineering products required for project life-cycle and technical reviews. These products are of value to key stakeholders on the project such as the Lead Systems Engineer, Project Chief Engineer, Project Manager, Customer, Review Board, and others. The user may need to discuss the format of the artifacts with the key stakeholders, as the format may be different from what has been previously provided. The guidance in this paper is useful to system modelers and to people who are unfamiliar with MBSE, in illustrating how MBSE can be used to implement systems engineering processes.

\section{Approach}

The NASA systems engineering engine in the NPR identifies the processes that systems engineers use for their work. Each process has outputs, some of which are products that are required products for reviews. The NPR contains a table that lists the required products and their maturity at each of the major reviews. A few additional products not listed as required, such as interface definitions and implementation plans, are considered primary products. Since a multitude of systems engineering products can be generated through the course of a project above and beyond those needed for major reviews, the scope of the effort presented in this paper is that of the required and primary systems engineering products for NASA project life-cycle and technical reviews. The required systems engineering products are listed below, by review:

1. Mission Concept Review: baselined stakeholder identification and expectations definitions; baselined concept definition; approved measures of effectiveness definition.

2. System Requirements Review: baselined systems engineering management plan for projects, single-project programs, and one-step Announcement of Opportunity programs; baselined requirements.

3. Mission Definition Review/System Definition Review: approved technical performance measure definitions; baselined architecture definition; baselined allocation of requirements to next lower level; initial trend of required leading indicators; baseline systems engineering management plan for uncoupled, loosely coupled, tightly coupled, and two-step Announcement of Opportunity programs.

4. Preliminary Design Review: preliminary design solution definition.

5. Critical Design Review: baseline detailed design.

6. System Integration Review: updated integration plan; preliminary verification and validation results.

7. Operational Readiness Review: updated operational plans; updated operational procedures; preliminary decommissioning plans.

8. Flight Readiness Review: baseline disposal plans; baseline verification and validation results; final certification for flight/use.

9. Decommissioning Review: baseline decommissioning plans.

10. Disposal Readiness Review: updated disposal plans.

Sections III to XVI contain information for each of the major systems engineering products listed above. Each of these sections contains subsections that identify artifacts necessary to produce the products and is displayed in the following format: artifacts, model elements and relationships, model validation, and additional details. The artifacts subsection lists products commonly generated for reviews and the SysML equivalent artifacts. The model elements and relationships subsection explains which SysML table, matrix, model element, diagram, relationships, or other elements would generate or contribute to this artifact. The model validation subsection has common questions that can be considered to evaluate completeness and accuracy of model artifacts relative to the model's intent using basic 
SysML modeling queries. There are many validation techniques not described here, such as scripting and visualizations, that can be used; the ones listed are suggestions.

Since many of the system model elements are used across the system life-cycle and in multiple artifacts, duplicative information is referenced and not repeated. Some of the model elements may be put into a system model earlier than necessary for a particular review and serve as placeholders for later use. The maturity of the model elements, diagrams, and information in a system model depends on where the project is in its lifecycle. In the beginning, the model incorporates high level information as the project is still being developed. During this phase, development of stakeholder identification and expectations definition, concept definition, measures of effectiveness, cost and schedule, system engineering management plan, and requirements are modeled. Many model elements will contain only key or placeholder information. As the project matures, more information is added to the model such as technical performance measures, architecture, lower level requirements, interfaces, and activity flows, to name a few. These all come together to support testing, verification and validation, flight certification, mission scenarios, and mission operations.

\section{Stakeholder Identification and Expectations Definition}

The stakeholders are identified within the model, linked to their needs, goals, and objectives (NGOs); wants; and constraints. This is useful during change impact assessments, as the systems engineer can determine which stakeholders will be affected if a NGO changes or cannot be satisfied.

\section{A. Artifacts}

The artifacts used to identify the stakeholders and their expectations, in general, are listed in Table 1.

Table 1. Stakeholder and expectations artifacts.

\begin{tabular}{|l|l|}
\hline Stakeholder and Expectations Artifacts & Model Artifact \\
\hline List that identifies customers and stakeholders & Table. \\
\hline List of expectations (needs, wants, desires, capabilities, and constraints) & Table or matrix. \\
\hline Traceability of stakeholder expectations to stakeholders & Table or matrix. \\
\hline List of expectation allocated to stakeholders & Table or matrix. \\
\hline Priority of the expectation & Table. \\
\hline Other aspects of the expectations, such as how they are being satisfied & Table or matrix. \\
\hline
\end{tabular}

\section{B. Model Elements and Relationships}

This section discusses two possible ways to capture stakeholder information. The first is to use the SysML elements of an actor and a requirement block. The second is to use the SysML elements of a stakeholder actor and a concern. There are advantages and disadvantages to both approaches that are not discussed here as it is beyond the scope of this paper. The model elements and relationships for both approaches are listed in Table 2.

Table 2. Stakeholder and expectations model elements and relationships.

\begin{tabular}{|c|c|c|}
\hline Approaches & $\begin{array}{l}\text { Stakeholder and Expectations } \\
\text { Elements }\end{array}$ & Model Element and Relationship \\
\hline \multirow{5}{*}{$\begin{array}{l}\text { Using actor } \\
\text { and } \\
\text { requirement } \\
\text { block model } \\
\text { elements }\end{array}$} & Customer and Stakeholder & Actor or Actor with the "stakeholder" stereotype. \\
\hline & Expectations & Requirement block. \\
\hline & $\begin{array}{l}\text { Traceability between stakeholders and } \\
\text { expectations }\end{array}$ & $\begin{array}{l}\text { Trace relationship from the requirement block to the } \\
\text { actor. }\end{array}$ \\
\hline & $\begin{array}{l}\text { Satisfaction of stakeholder } \\
\text { expectations }\end{array}$ & $\begin{array}{l}\text { Satisfy relationship from another model element such } \\
\text { as a diagram, activity, or block to the requirement } \\
\text { block. }\end{array}$ \\
\hline & Expectation Priority & Attribute of a requirement block. \\
\hline \multirow{2}{*}{$\begin{array}{l}\text { Using } \\
\text { stakeholder } \\
\text { actor and }\end{array}$} & Customer and Stakeholder & Actor with the "stakeholder" stereotype. \\
\hline & Expectations & $\begin{array}{l}\text { Comment (note that a comment becomes a concern } \\
\text { when the relationship between the comment and } \\
\text { stakeholder is applied). }\end{array}$ \\
\hline
\end{tabular}




\begin{tabular}{|l|l|l|}
\hline Approaches & $\begin{array}{l}\text { Stakeholder and Expectations } \\
\text { Elements }\end{array}$ & Model Element and Relationship \\
\hline $\begin{array}{l}\text { concern model } \\
\text { elements }\end{array}$ & $\begin{array}{l}\text { Traceability between stakeholders and } \\
\text { expectations }\end{array}$ & $\begin{array}{l}\text { Anchor relationship from the concern to the } \\
\text { stakeholder. }\end{array}$ \\
\cline { 2 - 3 } & Satisfaction of stakeholder concerns & $\begin{array}{l}\text { Concern is anchored to a model element. This can be } \\
\text { shown in a table as an "Annotated Element". }\end{array}$ \\
\cline { 2 - 3 } & Expectation Priority & Attribute of a comment block. \\
\hline
\end{tabular}

Figure 1 shows an example using requirement blocks to capture the NGO and then traced to the corresponding stakeholder that established the NGO. It also shows how the satisfy relationship indicates that a requirement is developed to satisfy a NGO.

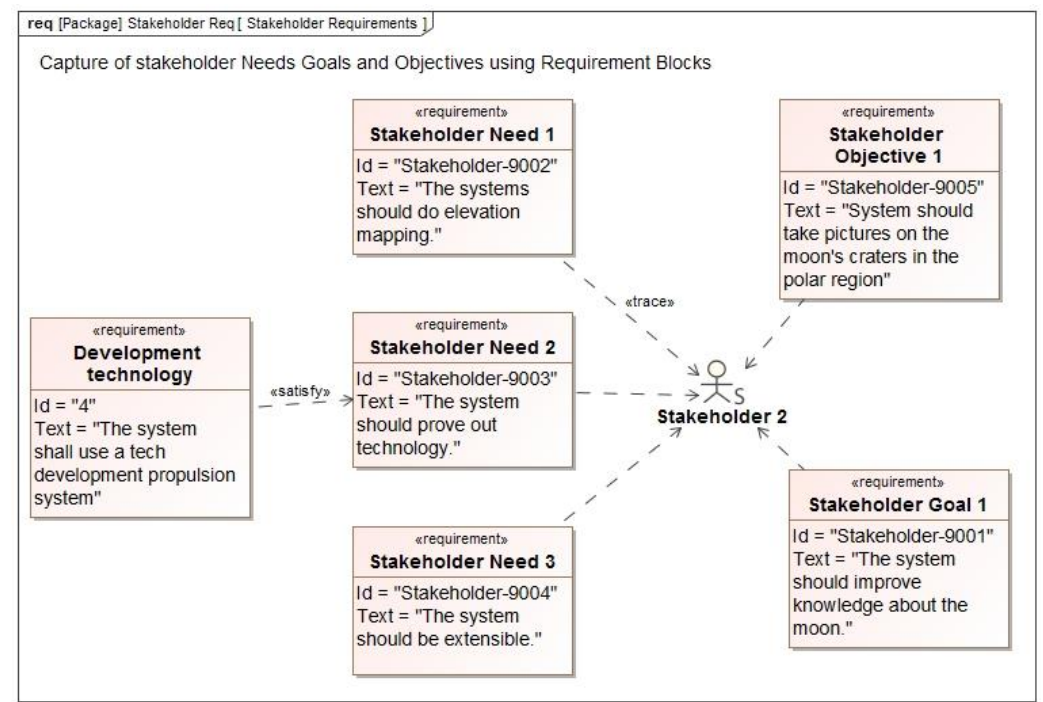

Figure 1. Stakeholder requirements captured using requirement blocks.

Figure 2 below shows an example of how the comments or concerns are displayed in a table. It also shows how the stakeholder NGOs are being satisfied as noted in the annotated element column and which stakeholder is interested. The Annotated Element column shows the model elements that are anchored to the concern and in turn satisfy it.

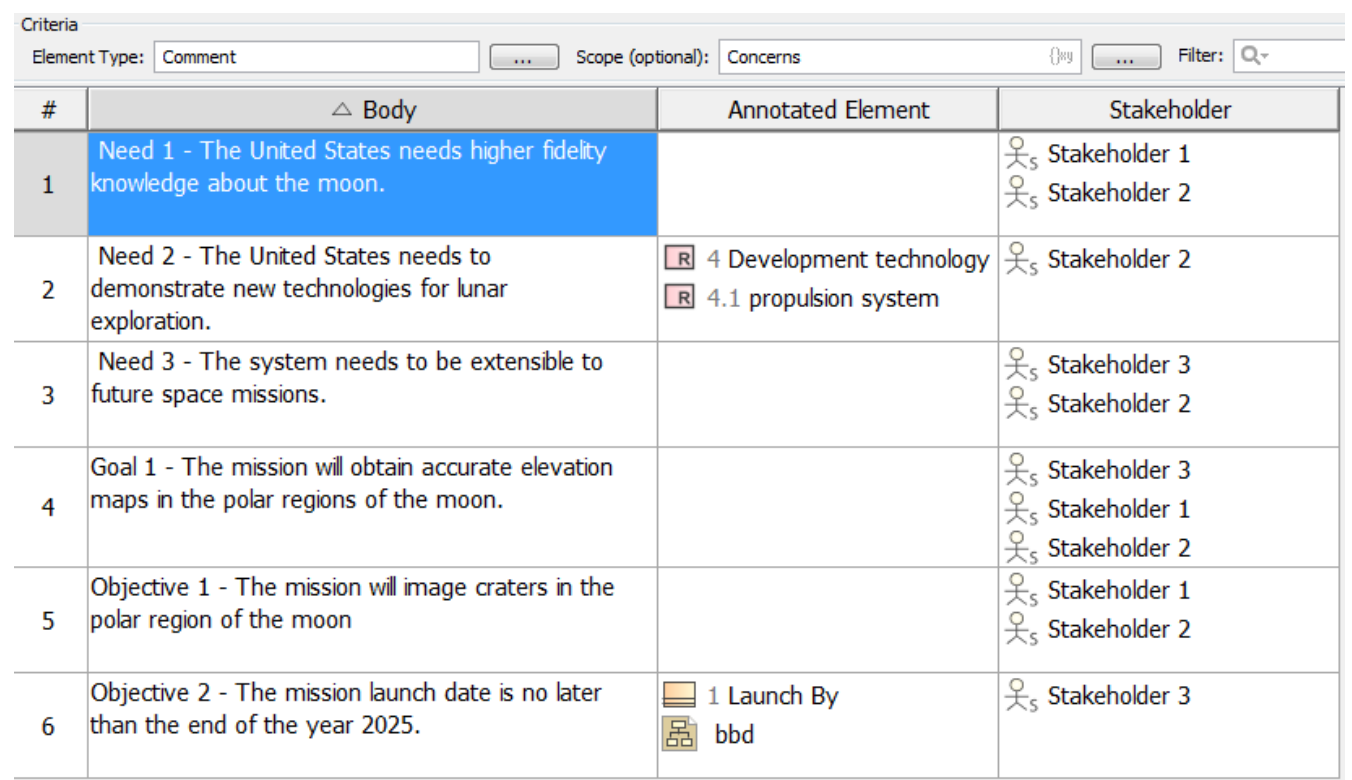

Figure 2. Stakeholder requirements captured using comments. 


\section{Model Validation Information}

Validation is captured in many ways and at various levels of maturity. The main ways to show compliance are described in Table 3 . These questions are only a starting point and they can be performed using model-generated tables and diagrams.

Table 3. Stakeholder identification and expectations definition validation.

\begin{tabular}{|l|l|}
\hline Validation Question & Validation Method \\
\hline $\begin{array}{l}\text { Does every expectation have at least } \\
\text { one associated stakeholder? }\end{array}$ & $\begin{array}{l}\text { Use an allocation matrix that contains stakeholders, expectations, and the } \\
\text { allocation relationships to evaluate whether each expectation is allocated } \\
\text { to a stakeholder. }\end{array}$ \\
\hline $\begin{array}{l}\text { For later in the life cycle, have all } \\
\text { the expectations been satisfied? }\end{array}$ & $\begin{array}{l}\text { This can be shown two ways: 1) a satisfy matrix that contains } \\
\text { expectations and the satisfy relationships to model elements; or 2) a table } \\
\text { that lists all the expectations and model elements that satisfy the } \\
\text { expectations. }\end{array}$ \\
\hline
\end{tabular}

\section{More Detail}

Expectations can be major and minor concerns. Minor expectations can be smaller tasks or analyses that need to be completed later in the project life-cycle, and if useful to the systems engineering planning effort, may be captured within the model.

\section{Concept Definition}

In starting any project a concept of operations (ConOps) for the mission or system is needed to detail the mission lifecycle and objectives. It is necessary to have an understanding of the whole mission and project timeline to design the system. The ConOps also helps define the high-level architectural structure, requirements, activities, and functions the system must address or perform and establishes trade space boundaries. To begin a project, an overview of the project scenario is created at a very high level. This overview could include events or activities, such as launch, payload separation, travel to locations, perform science, etc. These events are decomposed into smaller activities or functions. For example, the launch event might be decomposed into smaller activities such as install payload, load propellant, and trickle charge batteries. The ConOps is updated with greater fidelity as the project progresses and as more details of the mission, objectives, and functions are defined.

For clarity, for this document, an activity can be decomposed into multiple functions, where a function is at its lowest level of decomposition for either the function or modeling level. For simplicity, the term function is used, in this section, to represent both activities and functions and not to get it confused with activity diagrams.

\section{A. Artifacts}

The artifacts for concept definition, in general, are listed in Table 4 .

\section{Table 4. Concept definition artifacts.}

\begin{tabular}{|l|l|}
\hline Concept Definition Artifacts & Model Artifact \\
\hline Mission scenario and functions & Use case diagram. \\
\hline Top-level system architecture concept & Block definition diagram. \\
\hline System functions & Use case diagram and activity diagram. \\
\hline System functional flows (data and activity) & Activity diagram. \\
\hline Functional decomposition & Block definition diagram or activity tree diagram. \\
\hline
\end{tabular}

\section{B. Model Elements and Relationships}

The model elements and relationships commonly utilized in the development of concept definition are listed in Table 5. The table is broken into four groups: mission scenarios, top-level architecture and defining functions; functional flow using activity diagrams; functional decomposition; and common element and relationship. 
Table 5. Concept definition model elements and relationships.

\begin{tabular}{|c|c|c|}
\hline Concept Definition & Elements & Model Element and Relationship \\
\hline \multirow{7}{*}{$\begin{array}{l}\text { Mission scenarios, top- } \\
\text { level architecture and } \\
\text { defining functions }\end{array}$} & Stakeholder & Actor that interacts with the system. \\
\hline & $\begin{array}{l}\text { Top level architectural } \\
\text { elements of system-of- } \\
\text { interest }\end{array}$ & Blocks. \\
\hline & External system or subsystem & $\begin{array}{l}\text { Blocks. These are systems, subsystems, or } \\
\text { environments that are outside and interface with the } \\
\text { system-of-interest. }\end{array}$ \\
\hline & $\begin{array}{l}\text { Design boundary or boundary } \\
\text { of technical effort }\end{array}$ & $\begin{array}{l}\text { System boundary. The system boundary signifies the } \\
\text { functional boundary of the system-of-interest. }\end{array}$ \\
\hline & System capabilities & $\begin{array}{l}\text { Use case. The use case shows describes the } \\
\text { capabilities the system needs to perform, from the } \\
\text { stakeholder point of view. }\end{array}$ \\
\hline & $\begin{array}{l}\text { Stakeholder Interaction with } \\
\text { system capabilities }\end{array}$ & $\begin{array}{l}\text { Use case diagram, association relationship between } \\
\text { the actors and the capabilities they use or perform } \\
\text { within the system-of-interest. }\end{array}$ \\
\hline & $\begin{array}{l}\text { Decomposition of functions } \\
\text { and activities }\end{array}$ & $\begin{array}{l}\text { Refine or satisfy relationship to provide more details } \\
\text { of the use case. }\end{array}$ \\
\hline \multirow[t]{5}{*}{$\begin{array}{l}\text { Functional Flow (using } \\
\text { Activity Diagrams) }\end{array}$} & $\begin{array}{l}\text { Multiple uses of the same } \\
\text { functions }\end{array}$ & $\begin{array}{l}\text { Action or call behavior action. A call behavior action } \\
\text { is an instance of a function or activity that is used } \\
\text { multiple times or calls other activity flows. The } \\
\text { action is used at the lowest level of decomposition. } \\
\text { The lowest level that is modeled is determined by the } \\
\text { level of detail required by the project. }\end{array}$ \\
\hline & $\begin{array}{l}\text { Allocation of functions to } \\
\text { system or subsystem } \\
\text { interactions }\end{array}$ & $\begin{array}{l}\text { Swim lanes. Swim lanes capture which block } \\
\text { performs which activities when allocated. At the high } \\
\text { level, it may be the system. As the activities are } \\
\text { decomposed, the swim lanes may become subsystems } \\
\text { or components. }\end{array}$ \\
\hline & Data interfaces & $\begin{array}{l}\text { Activity parameter nodes and pins on the action. This } \\
\text { is useful to capture what input a function needs } \\
\text { before it can execute or what outputs a function } \\
\text { creates that other functions need. }\end{array}$ \\
\hline & Sequencing of functions & $\begin{array}{l}\text { Activity diagrams show the functions and the order } \\
\text { or sequence of the functions. As the project matures, } \\
\text { the functions are decomposed. Activity diagrams may } \\
\text { contain many functions. Control indicated the order } \\
\text { in which system functions must occur. }\end{array}$ \\
\hline & $\begin{array}{l}\text { Data passed between } \\
\text { functions }\end{array}$ & $\begin{array}{l}\text { Object flows. These can represent signals, power, } \\
\text { data, fluids, etc. }\end{array}$ \\
\hline \multirow[t]{2}{*}{$\begin{array}{l}\text { Functional } \\
\text { Decomposition }\end{array}$} & Functions & $\begin{array}{l}\text { Activities. These can also be depicted in an activity } \\
\text { tree in a Block Definition Diagram to help maintain } \\
\text { appropriate and consistent level of decomposition } \\
\text { throughout. }\end{array}$ \\
\hline & Decomposition of functions & $\begin{array}{l}\text { Direct composition relationship. The relationship } \\
\text { should also have the AdjunctProperty stereotype so } \\
\text { the usage of the function in functional flows becomes } \\
\text { a part property of the parent function. }\end{array}$ \\
\hline Common & $\begin{array}{l}\text { Associating functions to } \\
\text { requirements }\end{array}$ & $\begin{array}{l}\text { Satisfy relationship. This allows the project to know } \\
\text { if a specific function or activity is needed and can } \\
\text { show compliance to requirements. }\end{array}$ \\
\hline
\end{tabular}




\section{Model Validation Information}

The main ways to show compliance are described in Table 6 . These questions are only a starting point and they can be performed using model-generated tables and diagrams.

Table 6. Concept definition validation.

\begin{tabular}{|l|l|}
\hline Validation Question & Validation Method \\
\hline $\begin{array}{l}\text { Does each function have a } \\
\text { corresponding requirement } \\
\text { identified? }\end{array}$ & $\begin{array}{l}\text { A matrix showing all the activities related to requirements via a satisfy } \\
\text { relationship can be used to validate the completeness of identified } \\
\text { requirements relative to identified functions. }\end{array}$ \\
\hline $\begin{array}{l}\text { Have the function been allocated to } \\
\text { an owning system or subsystem? }\end{array}$ & $\begin{array}{l}\text { This is done using a matrix or table listing the functions assigned to a } \\
\text { system or subsystem via the allocate relationship. }\end{array}$ \\
\hline $\begin{array}{l}\text { Have all the identified functions (as } \\
\text { part of the decomposition) been } \\
\text { utilized somewhere in a functional } \\
\text { flow? }\end{array}$ & A matrix showing the usages of the functions. \\
\hline
\end{tabular}

\section{More Detail}

Top-level capabilities of the system-of-interest are modeled as use cases. Use cases refine stakeholder expectations (requirements). Relationships among use cases, actors, the system-of-interest, boundaries, constraints, and environments are modeled in use case diagrams or in a block definition diagram as a system context. System behaviors, are modeled as actions. Actions can be allocated to other model elements and defined as activities. Relationships among functions, e.g. the order in which they should occur or functional interfaces, are shown on activity diagrams.

\section{Measures of Effectiveness (MOE), Measures of Performance (MOP) and Technical Performance Measures (TPM)}

MOE, MOP, and TPM are all captured the same in the modeling world. The only difference is in the calculations performed with them and the relationships among the model elements. MOE are the operational measures of success and are intended to focus on how well the mission operational objectives are can be achieved from the mission success criteria and are derived from the stakeholder's expectations. MOP are measures that characterize physical or functional attributes relating to the system and are typically derived from MOE. TPM are derived from the MOE and MOP. They are critical or key for mission success. TPM are measures such as mass, availability, mobility, user or operator comfort, CPU capacity, and parameters associated with critical events during operations.

\section{A. Artifacts}

The artifacts used for MOE, MOP and TPM, in general, are listed in Table 7.

Table 7. MOE, MOP and TPM artifacts.

\begin{tabular}{|l|l|}
\hline $\begin{array}{l}\text { Measures of Effectiveness (MOE), Measures of Performance } \\
\text { (MOP) and Technical Performance Measures (TPM) Artifacts }\end{array}$ & Model Artifact \\
\hline Metric (MOE, MOP, or TPM) & Instance. \\
\hline Metric (MOE, MOP, or TPM) to NGO(s) traceability & Table. \\
\hline Metric (MOE, MOP, or TPM) to requirements traceability & Table. \\
\hline MOE, MOP and TPM decomposition & Matrix. \\
\hline Tracking trends & $\begin{array}{l}\text { See section X, Required Leading Indicator } \\
\text { Trends. }\end{array}$ \\
\hline
\end{tabular}

\section{B. Model Elements and Relationships}

Creating MOE, MOP and TPM using parametrics may be difficult to set up. Once accomplished, it is easier to collect, manage, and see trends. Many of the model elements and relationships in this section are setting up parametrics. It is beneficial to reference the MBSE tool-of-choice user guide. Start off small and then increase the parametric detail as needed, rather than starting off too large with too many variables to troubleshoot initially. The model elements and relationships for MOE, MOP, and TPM are listed in Table 8. 
Table 8. MOE, MOP and TPM model elements and relationships.

\begin{tabular}{|c|c|}
\hline $\begin{array}{l}\text { Measures of Effectiveness (MOE), } \\
\text { Measures of Performance (MOP) } \\
\text { and Technical Performance } \\
\text { Measures (TPM) }\end{array}$ & Model Element and Relationship \\
\hline $\begin{array}{l}\text { Metric value associated with MOE, } \\
\text { MOP, and TPM }\end{array}$ & $\begin{array}{l}\text { Parameter owned by a constraint block. The constraint block holds the } \\
\text { value that is used to identify a pass fail when compared to the calculation } \\
\text { results. }\end{array}$ \\
\hline System and subsystem & Block. This block is used as the owning system of the constraint block. \\
\hline $\begin{array}{l}\text { Value used in calculating } \\
\text { parameter(s) to compare with } \\
\text { metrics }\end{array}$ & $\begin{array}{l}\text { Value attribute within the system/subsystem/component block it } \\
\text { represents. }\end{array}$ \\
\hline $\begin{array}{l}\text { Equation to calculate parameter(s) to } \\
\text { compare with metrics }\end{array}$ & $\begin{array}{l}\text { Constraint block. The constraint block holds the constraint equation the } \\
\text { MOE/MOP are assessed against, and the parameters necessary to } \\
\text { populate the equation. The parametric diagram assigns the values for } \\
\text { which the equation need to execute. Note that the equation could be a } \\
\text { series of equations. }\end{array}$ \\
\hline Results from calculations & $\begin{array}{l}\text { Instances. When performing parametric calculations, instances are used } \\
\text { for generating them. Performing these calculations at key decision points } \\
\text { and saving the data elsewhere, would allow the model to show the } \\
\text { changes of the TPMs over the life of the project. }\end{array}$ \\
\hline $\begin{array}{l}\text { Associating metric to a } \\
\text { system/subsystem/component }\end{array}$ & Direct composition. \\
\hline Associating a metric to an NGO & A satisfy relationship to NGO or concern is anchored to the metric. \\
\hline Associating a metric to requirement & $\begin{array}{l}\text { A contains relationship is used the requirement and the related constraint } \\
\text { block, or block definition diagrams with the constraint blocks and their } \\
\text { related elements. }\end{array}$ \\
\hline
\end{tabular}

\section{Model Validation Information}

Validation is captured in many ways and at various levels of maturity. The main ways to show compliance are described in Table 9. These questions are only a starting point and they can be performed using model-generated tables and diagrams.

Table 9. MOE, MOP and TPM validation.

\begin{tabular}{|l|l|}
\hline Validation Question & Validation Method \\
\hline $\begin{array}{l}\text { Which MOE, MOP or TPM satisfy a } \\
\text { concern? }\end{array}$ & $\begin{array}{l}\text { Table showing the MOP and TPM with their related model elements via } \\
\text { the satisfy relationship. }\end{array}$ \\
\hline $\begin{array}{l}\text { Which MOP and TPM are related to } \\
\text { a requirement, system or subsystem? }\end{array}$ & $\begin{array}{l}\text { Table showing the MOP and TPM with their related model elements. The } \\
\text { relationship used is dependent on the project. }\end{array}$ \\
\hline $\begin{array}{l}\text { Have the constraint equations been } \\
\text { implemented correctly in the model? }\end{array}$ & $\begin{array}{l}\text { Run a known configuration to show that the model configuration } \\
\text { produces the expected results. }\end{array}$ \\
\hline
\end{tabular}

\section{More Detail}

Quantitative TPM can be used in parametric diagrams. Figure 3 shows an example of a block definition diagram that would be used to perform a system mass roll-up. The system blocks have value properties of mass and total mass. The mass value is the mass for the block that is contained only within that block and not in lower-level blocks. Total mass for a block is the mass of the block added to the rolled-up mass from lower-level system blocks. For example, the total mass for System 3 is the rolled-up mass value from lower-level blocks Subsystems 3a and 3b, and the mass of System 3 that is not within Subsystems 3a and 3b. The Mass_rollup_pattern has a generalization relationship to all model elements associated within the calculation which is not shown. 


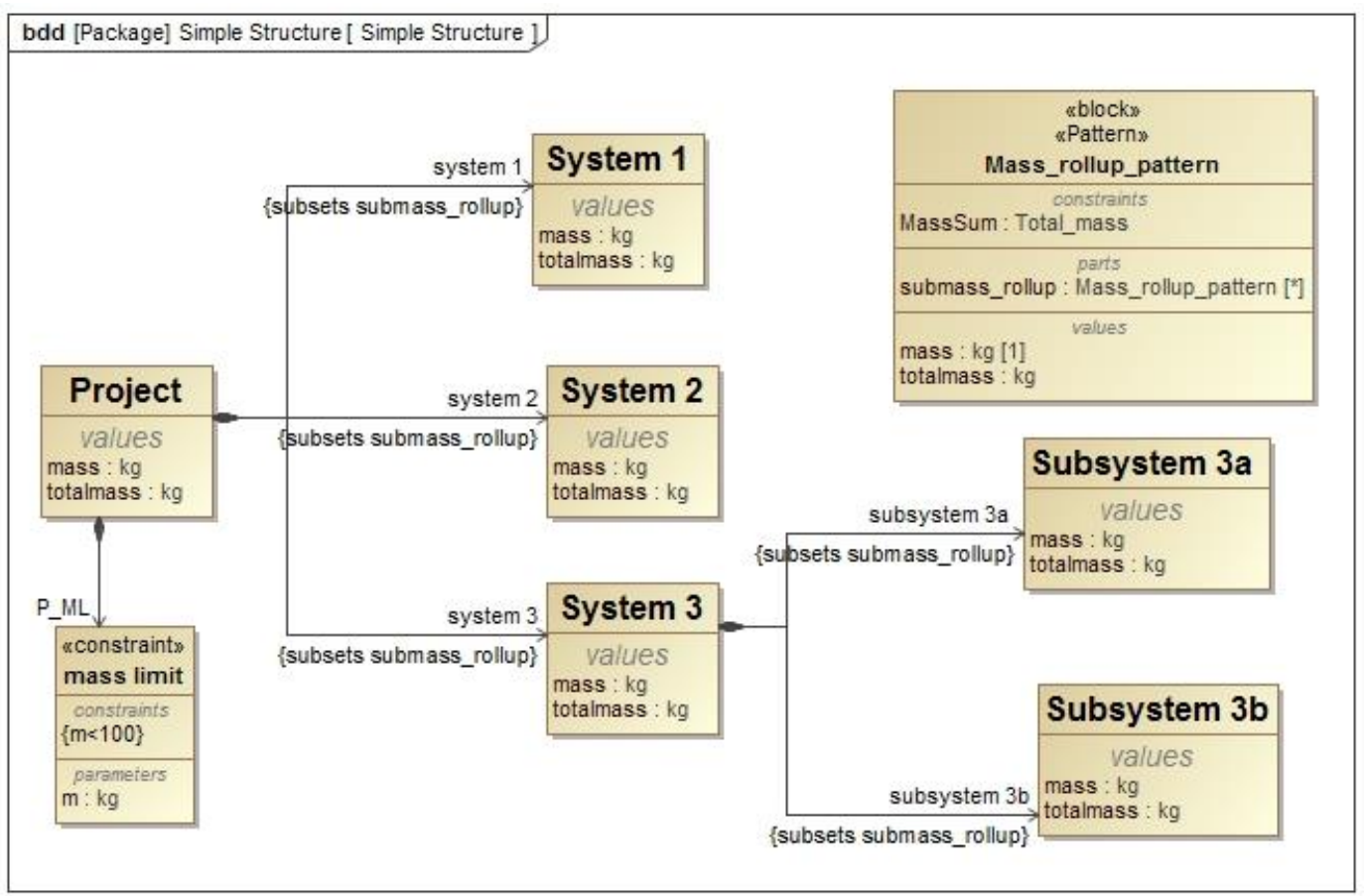

Figure 3. System block diagram set up for TPM.

Figure 4 shows the parametrics based on the Mass_rollup_pattern. The parametric diagram is where the value properties are assigned to parameters on the constraint. The model has a constraint block for the mass roll-up equation.

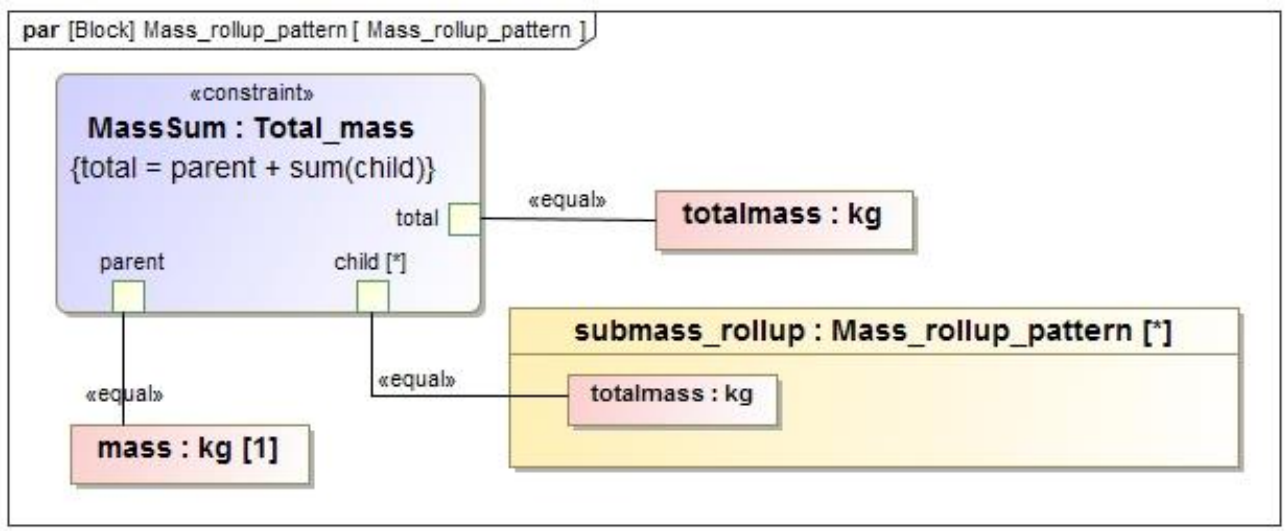

Figure 4. Parametric diagram for a mass roll-up.

Based on Figure 3 and Figure 4, calculations on instances are performed. Table 10 shows the mass roll-up instances over the course of ten days of work. An additional constraint block, not shown, performs trending and validates that the mass margins are met. For this example, the mass limit is $100 \mathrm{~kg}$. The table allows the project personnel to see trends and know when there is a failure to meet a metric. 
Table 10. Mass roll-up instance for mass trends.

\begin{tabular}{|c|c|c|c|c|c|c|c|c|}
\hline$\#$ & Name & $\begin{array}{l}\text { P_ML } \\
\text { : mass } \\
\text { limit }\end{array}$ & $\begin{array}{l}\text { totalMass } \\
\quad: \mathrm{kg}\end{array}$ & $\begin{array}{c}\text { system } \\
\text { 1.totalMass } \\
\text { : } \mathrm{kg}\end{array}$ & $\begin{array}{l}\text { system } \\
\text { 2.totalMass } \\
: \mathrm{kg}\end{array}$ & $\begin{array}{l}\text { system } \\
\text { 3.totalMass } \\
\text { : } \mathrm{kg}\end{array}$ & $\begin{array}{c}\text { system } \\
\text { 3.subsystem } \\
\text { 3a.totalMass } \\
\text { : kg }\end{array}$ & $\begin{array}{c}\text { system } \\
\text { 3.subsystem } \\
\text { 3b.totalMass } \\
\text { : kg }\end{array}$ \\
\hline 1 & $\begin{array}{c}\text { project } \\
06-01- \\
2016\end{array}$ & pass & 75.0 & 10.0 & 15.0 & 50.0 & 25.0 & 25.0 \\
\hline 2 & $\begin{array}{c}\text { project } \\
09-01- \\
2016\end{array}$ & pass & 95.0 & 10.0 & 25.0 & 60.0 & 25.0 & 35.0 \\
\hline 3 & $\begin{array}{c}\text { project } \\
06-05- \\
2017\end{array}$ & pass & 93.0 & 10.0 & 25.0 & 58.0 & 21.0 & 37.0 \\
\hline 4 & $\begin{array}{c}\text { project } \\
06-06- \\
2017\end{array}$ & pass & 97.0 & 14.0 & 25.0 & 58.0 & 21.0 & 37.0 \\
\hline 5 & $\begin{array}{c}\text { project } \\
06-10- \\
2017\end{array}$ & fail & 105.0 & 17.0 & 28.0 & 60.0 & 21.0 & 39.0 \\
\hline
\end{tabular}

\section{Cost and Schedule for Technical Implementation}

Cost and schedule currently are usually kept in an external tool because of the amount of detail. However, some information can be kept within the model. The data can be exported to be combined with external data. This section will describe how the data can be stored within the MBSE tool and how the data can be shown. It does not go into how the information can be imported or exported from the model. This section does not show the full extent of all the cost and schedule artifacts, but gives an overall idea of how to capture the data. Section VII, System Engineering Management Plan, has some additional information on this topic.

\section{A. Artifacts}

The artifacts used for cost and schedule artifacts, in general, are listed in Table 11.

Table 11. Cost and schedule artifacts.

\begin{tabular}{|l|l|}
\hline Cost and Schedule artifacts & Model Artifact \\
\hline Key events & Table to show event dates or Activity diagram to show event flows. \\
\hline Cost projections & $\begin{array}{l}\text { Table with the system, subsystem, and component attributes and the } \\
\text { resultant from the parametric output. }\end{array}$ \\
\hline Variance from one date to another & Instance table. \\
\hline Completion or delays of activities & Table. \\
\hline $\begin{array}{l}\text { Work Breakdown Structure (WBS) } \\
\text { elements structure }\end{array}$ & Block diagram. \\
\hline
\end{tabular}

\section{B. Model Elements and Relationships}

The model elements that would be used are listed in Table 12. Some of the elements listed below are attributes. Depending on how the model is structured, these attributes could be part of a stereotype, generalization from another block, or block specific. How the attribute is defined is not discussed.

Table 12. Cost and schedule model elements and relationships.

\begin{tabular}{|l|l|}
\hline Cost and Schedule & Model Element and Relationship \\
\hline WBS element & $\begin{array}{l}\text { Value property or attribute within a block. The value properties can } \\
\text { be typed to capture WBS properties so that budgets, work }\end{array}$ \\
\hline
\end{tabular}




\begin{tabular}{|l|l|}
\hline Cost and Schedule & Model Element and Relationship \\
\hline Cost values & $\begin{array}{l}\text { authorizations, schedules and such can be correlated together. These } \\
\text { blocks can be then related to architecture or requirement blocks. }\end{array}$ \\
\hline Schedule dates, key events dates, etc. & $\begin{array}{l}\text { Value property or attribute of a block defined as a real variable so it } \\
\text { can be used in a parametric calculation. }\end{array}$ \\
\hline Equation to do Cost or Schedule study & $\begin{array}{l}\text { Calue property or attribute of a block defined as a date variable. } \\
\text { example of performing calculations. }\end{array}$ \\
\hline
\end{tabular}

\section{Model Validation Information}

Validation is captured in many ways and at various levels of maturity. The main ways to show compliance are described in Table 13. These questions are only a starting point and they can be performed using model-generated tables and diagrams.

\section{Table 13. Cost and schedule validation.}

\begin{tabular}{|l|l|}
\hline Validation Question & Validation Method \\
\hline $\begin{array}{l}\text { Is the cost information being } \\
\text { calculated correctly? }\end{array}$ & $\begin{array}{l}\text { Can be validated by having a table with the information and manually } \\
\text { doing a check or comparing the results in an external tool. }\end{array}$ \\
\hline $\begin{array}{l}\text { Are all the events captured within } \\
\text { the model? }\end{array}$ & $\begin{array}{l}\text { Can be verified by creating a table listing all the events and the events } \\
\text { have all the necessary data the project requires. }\end{array}$ \\
\hline $\begin{array}{l}\text { Are all the events in the model } \\
\text { scheduled and costed? }\end{array}$ & $\begin{array}{l}\text { Can be validated by creating a table listing all the events with schedule } \\
\text { and cost data. Empty or missing cells indicate potentially missing data. }\end{array}$ \\
\hline
\end{tabular}

\section{More Detail}

When doing cost and schedule, it is important to make sure that the data is changed in only a single location, and that all calculations pull the information the same way. If updates are done in multiple locations, then data can become obsolete, knowing which is correct can be difficult, and finding the source of any errors can be difficult.

Using the model to capture cost or schedule information, each update can be captured and documented as an instance in the model. These instances can be shown in an instance table to can be used to perform trending analysis and for status.

\section{System Engineering Management Plan}

The System Engineering Management Plan (SEMP) is a living document that the project generates to define the technical integration methodologies and activities. The SEMP captures the processes the project uses and identifies the responsible party. The model may not contain all the information in its entirety that is in the SEMP. However, the system model can be used to generate sections of the document. Below are suggestions on how certain information is kept within the model.

\section{A. Artifacts}

The artifacts used for the SEMP, in general, are listed in Table 14.

Table 14. System Engineering Management Plan artifacts.

\begin{tabular}{|l|l|}
\hline SEMP artifacts & Model Artifact \\
\hline SEMP Document & $\begin{array}{l}\text { Output from the model using information from within the model, in } \\
\text { addition to information that supplements model-generated content. }\end{array}$ \\
\hline System Decomposition & Block definition diagram. \\
\hline WBS Layout & Block definition diagram. \\
\hline $\begin{array}{l}\text { Technical Summary of SEMP } \\
\text { sections }\end{array}$ & Artifact. \\
\hline $\begin{array}{l}\text { Responsibility and organizational } \\
\text { structure }\end{array}$ & Block definition diagram and allocation matrix. \\
\hline External or NASA Standard & $\begin{array}{l}\text { Block that contains attributes such as report name and report owner, } \\
\text { with external hyperlink. }\end{array}$ \\
\hline
\end{tabular}




\begin{tabular}{|l|l|}
\hline SEMP artifacts & Model Artifact \\
\hline $\begin{array}{l}\text { Project processes such as } \\
\text { Engineering Review Board and } \\
\text { Project Control Board }\end{array}$ & Activity diagrams. \\
\hline $\begin{array}{l}\text { Various processes such as } \\
\text { configuration management, SE } \\
\text { processes, waiver process, etc. }\end{array}$ & Activity diagram or sequence diagram to lay out the process. \\
\hline
\end{tabular}

\section{B. Model Elements and Relationships}

The model elements and relationships that are used in creating the SEMP artifacts are listed in Table 15.

Table 15. System Engineering Management Plan model elements and relationships.

\begin{tabular}{|l|l|}
\hline SEMP & Model Element and Relationship \\
\hline SEMP & $\begin{array}{l}\text { Package or content diagram. These diagrams contains folders or package } \\
\text { information that can be found elsewhere in the model in a single diagram. }\end{array}$ \\
\hline Textual content & $\begin{array}{l}\text { Artifact or comment. In the document world, it is the text part of the } \\
\text { document that describes a section. When sections are repeated in other } \\
\text { sections, it is better to capture the information in an artifact for easy } \\
\text { reference. Comments and text boxes can be used when information is } \\
\text { used for a single diagram. The textual content can be used to generate an } \\
\text { external document if necessary. }\end{array}$ \\
\hline $\begin{array}{l}\text { Personnel and organizations } \\
\text { associated with the project }\end{array}$ & Actors. These actors use an allocation relationship to the WBS structure. \\
\hline System component & Block. See section IX, Architecture Definition, for more information. \\
\hline WBS structure & $\begin{array}{l}\text { Block. The structure is very similar to defining the system components, } \\
\text { but instead of system and part, the blocks represent work packages. The } \\
\text { direct composite relationship is used to show the breakdown of the work } \\
\text { to system components. The black diamond is on the higher level and } \\
\text { points to the next level down. }\end{array}$ \\
\hline Project process activities & $\begin{array}{l}\text { Action block or call behavior action block. A control flow relationship is } \\
\text { used to between action blocks, to show the process flow. }\end{array}$ \\
\hline Organizational task allocation & $\begin{array}{l}\text { Swim lanes. Swim lanes capture which organization, such as project level } \\
\text { or team, performs the process function. }\end{array}$ \\
\hline Data interactions & $\begin{array}{l}\text { Activity parameter nodes and pins on the action block. This is useful } \\
\text { when showing what input is needed before the process activity can } \\
\text { proceed such as a change package and the outcome of that activity such } \\
\text { as a scheduled review date, for the process to continue. }\end{array}$ \\
\hline
\end{tabular}

\section{Model Validation Information}

Validation is captured in many ways and at various levels of maturity. The main ways to show compliance are described in Table 16. These questions are only a starting point and they can be performed using model-generated tables and diagrams.

Table 16. System Engineering Management Plan validation.

\begin{tabular}{|l|l|}
\hline Validation Question & Validation Method \\
\hline $\begin{array}{l}\text { Does the model have all the } \\
\text { processes that are required in a } \\
\text { SEMP? }\end{array}$ & $\begin{array}{l}\text { Package diagram or content diagram and verify that all required sections } \\
\text { contain the pertinent information. }\end{array}$ \\
\hline $\begin{array}{l}\text { Do the WBS elements have } \\
\text { allocations to an organization or } \\
\text { role? }\end{array}$ & Matrix with all the WBS allocated to an organization or role? \\
\hline
\end{tabular}




\begin{tabular}{|l|l|}
\hline Validation Question & Validation Method \\
\hline $\begin{array}{l}\text { Do the process elements have } \\
\text { owners (personnel or system) } \\
\text { associated with them? }\end{array}$ & Matrix. \\
\hline
\end{tabular}

\section{More Detail}

There are two ways of capturing the information necessary for creating a SEMP; a package diagram method as shown in Figure 5 or a content diagram shown in Figure 6. The SEMP outline used in Figures 5 and 6 is based on the guidance in Appendix D of NPR 7123.1B. ${ }^{1}$ As shown, it displays that a WBS structure diagram is created and associated with section 3.2 of the SEMP and the WBS allocation matrix diagram associated with section 4.0 of the SEMP. The difference between the two options is how the artifacts that satisfy the SEMP section are kept. In a package diagram, the SEMP information can be stored two ways: 1) an artifact is created inside the package and then the artifact is hyperlinked to the artifact within the model as shown in package 3.2 System Structure or 2) the artifact is stored within the package as shown in package 4.0 Technical Effort Integration. The artifact will not appear unless it is kept within the package location.

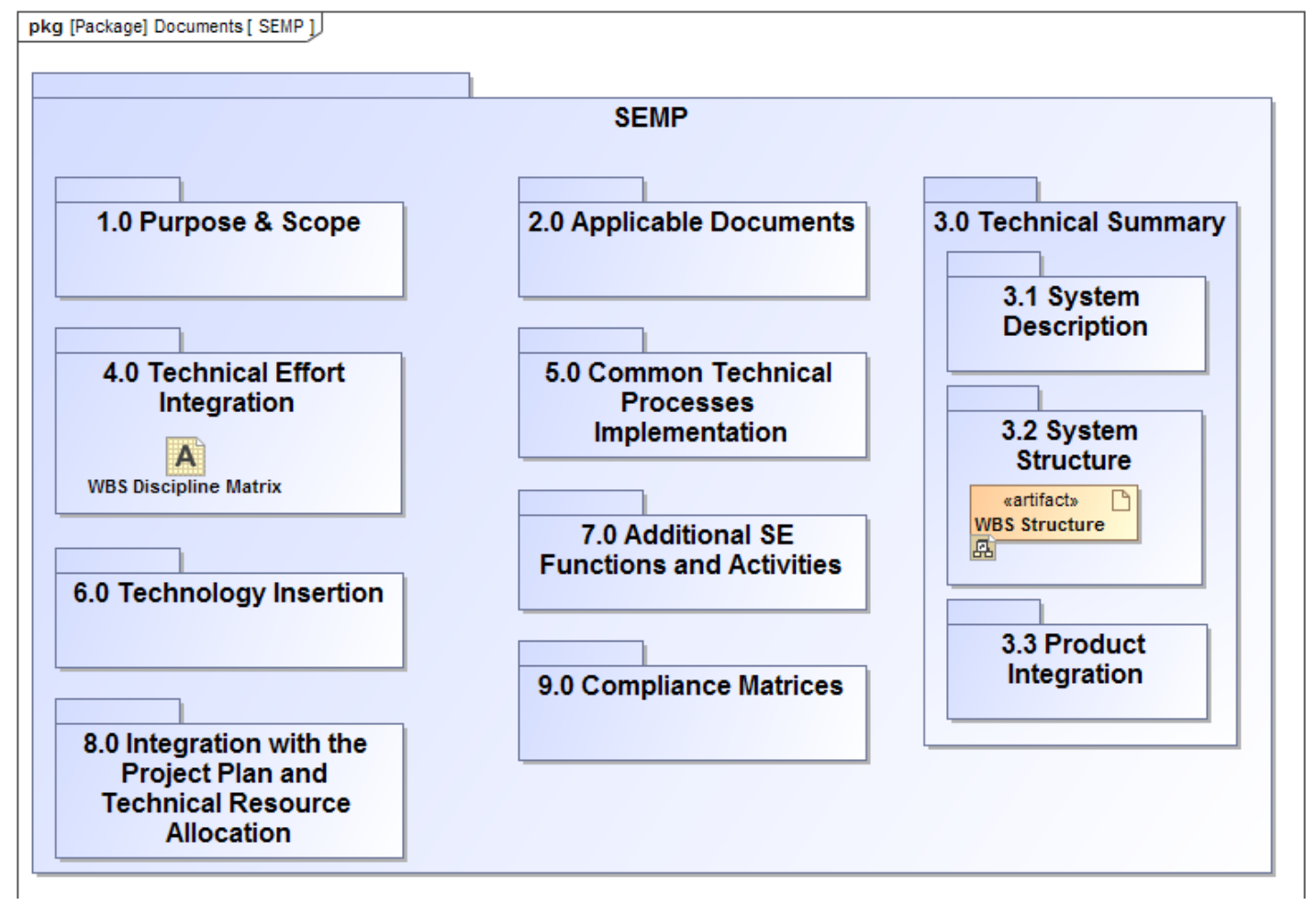

Figure 5. Package diagram for SEMP.

In a content diagram the artifact is dragged and dropped onto associated package which creates a hyperlink to the artifact within the model. Either way is acceptable and is a project decision on which to use. 


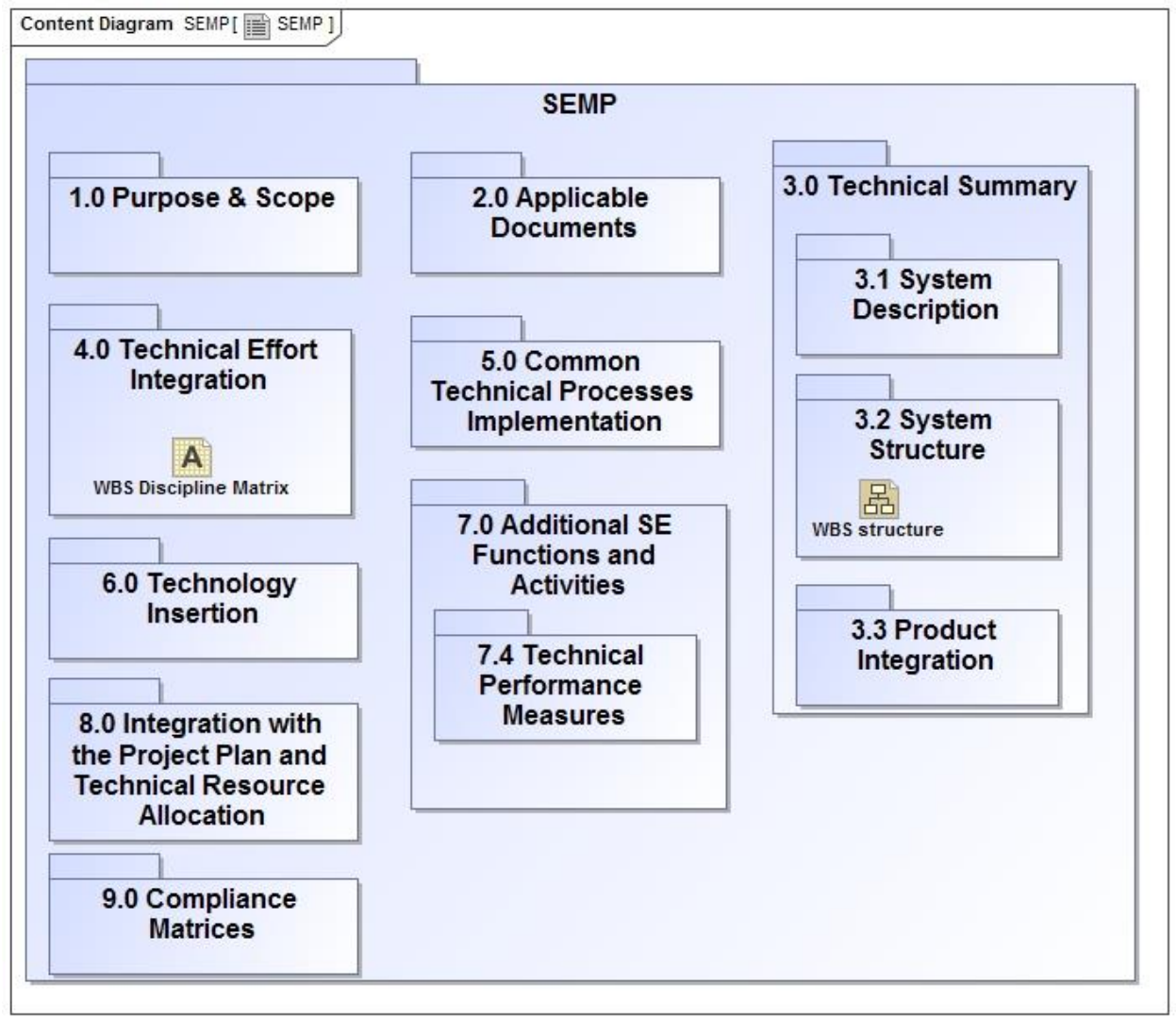

\section{Figure 6. Content diagram for SEMP.}

The WBS structure diagram shown in Figure 7 is an example WBS structure that based on a space-flight project from Work Breakdown Structure (WBS) Handbook, Appendix C. ${ }^{6}$ Details associated with the WBS elements can be added using generalization or stereotype to add attributes that are required by the project. Figure 8 shows the allocation of work to the organizations. Figure 7 and Figure 8 are the artifacts that are shown in Figures 5 and 6.

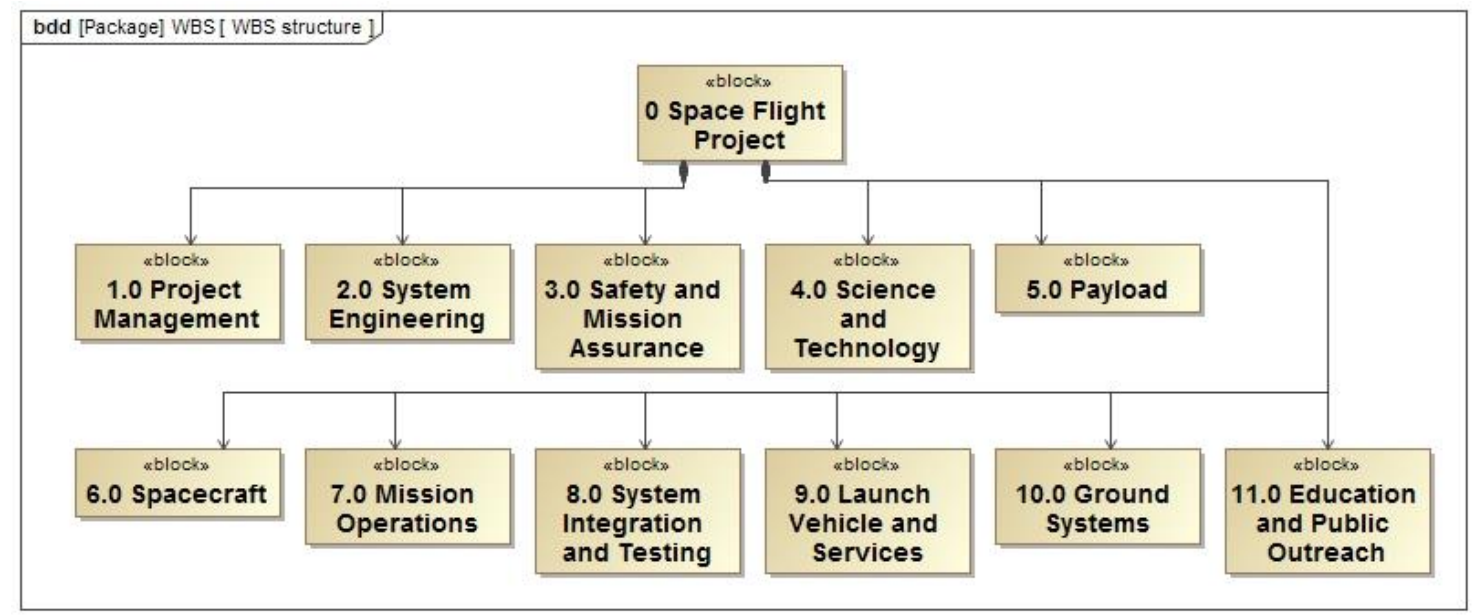

Figure 7. WBS package diagram. 


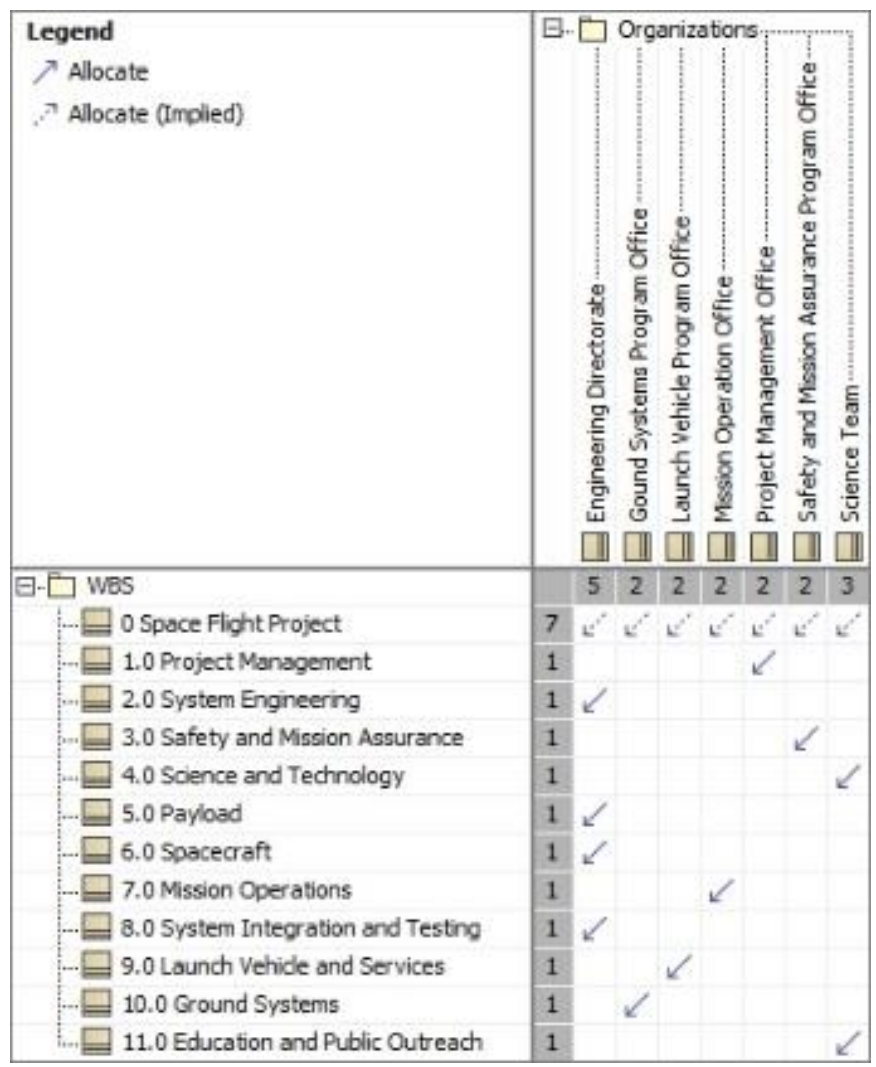

Figure 8. WBS discipline allocation matrix.

\section{Requirements and Allocation of Requirements to Next Lower Level}

Requirements are a way to state the physical and functional capabilities that a particular design, product or process must be able to perform. The requirement work starts at the very beginning during mission concept followed by decomposition. Requirement decomposition ends when the project is ready to make, buy or build. Requirements not only include the high level project and mission requirements, but also include technical, performance, interface, environmental, operational, reliability, safety, specialty and human factors. The requirements become more specific as they are further decomposed. The approach here is for text-based requirements.

\section{A. Artifacts}

The artifacts used to state, trace, and allocate requirements, in general, are listed in Table 17.

Table 17. Requirements artifact.

\begin{tabular}{|l|l|}
\hline Requirement Artifact & Model Artifact \\
\hline Requirements at various levels & Requirement diagrams. \\
\hline Requirement traceability & Requirement diagram or matrix. \\
\hline $\begin{array}{l}\text { Requirement allocation to systems, events, functions and } \\
\text { other relationships }\end{array}$ & Matrix. \\
\hline
\end{tabular}

\section{B. Model Elements and Relationships}

The model elements and relationships that capture requirements artifacts are listed in Table 18.

Table 18. Requirement model elements and relationships.

\begin{tabular}{|l|l|}
\hline Requirement & Model Element and Relationship \\
\hline $\begin{array}{l}\text { Technical and programmatic } \\
\text { requirement }\end{array}$ & Requirement block. \\
\hline
\end{tabular}




\begin{tabular}{|l|l|}
\hline Requirement & Model Element and Relationship \\
\hline Parent to child relationship & Derive, trace, or containment relationship. \\
\hline Requirement to other model elements & Satisfy or refine relationship. \\
\hline $\begin{array}{l}\text { Allocation of requirements to the next } \\
\text { level down system or subsystem }\end{array}$ & $\begin{array}{l}\text { Allocate relationship. The allocation relationship allows the next level } \\
\text { down to know which requirements are assigned to them and which are } \\
\text { not. }\end{array}$ \\
\hline $\begin{array}{l}\text { Requirements verified by a } \\
\text { verification event }\end{array}$ & $\begin{array}{l}\text { Verify relationship. A verification event can verify multiple } \\
\text { requirements. }\end{array}$ \\
\hline $\begin{array}{l}\text { Additional attributes of a requirement } \\
\text { block }\end{array}$ & $\begin{array}{l}\text { Requirement block stereotype. This stereotype is commonly used when } \\
\text { extra attributes are required for all requirements. Types of attributes that } \\
\text { could be added are: requirement status (draft, preliminary, baselined); } \\
\text { verification status (open, closed), and rationale to name a few. }\end{array}$ \\
\hline Measuring value in a requirement & $\begin{array}{l}\text { Value attribute within a block or requirement (if set as an attribute). } \\
\text { This value can be in a requirement field and then placed or referenced in } \\
\text { a constraint block for performing a mathematical relationship. }\end{array}$ \\
\hline Associating requirements to NGO & See section III, Stakeholder Identification and Expectations Definition. \\
\hline Associating functions to requirements & Satisfy relationship. \\
\hline
\end{tabular}

\section{Model Validation Information}

Validation is captured in many ways and at various levels of maturity. The main ways to show compliance are described in Table 19. These questions are only a starting point and they can be performed using model-generated tables and diagrams.

Table 19. Requirement validation.

\begin{tabular}{|l|l|}
\hline Validation Question & Validation Method \\
\hline $\begin{array}{l}\text { Does every requirement have a parent or a child } \\
\text { depending on the requirement level? }\end{array}$ & Matrix \\
\hline $\begin{array}{l}\text { Have the requirements been allocated to the physical } \\
\text { structure elements? }\end{array}$ & Allocation Matrix \\
\hline $\begin{array}{l}\text { Do the requirements have the necessary information } \\
\text { for the level of maturity? }\end{array}$ & Validation Scripts within the model, tables \\
\hline
\end{tabular}

\section{More Detail}

Requirement blocks are usually related to the following model elements: concerns, activity, functions, verification events, and blocks. These model elements are described in other sections within this paper. Relationships between the requirements and other model elements are created as the requirements are reviewed and baselined, and as more detail is added within the model.

Figure 9 shows an example of how attributes can be added to requirements and what they look like in the SysML requirement element after the stereotype is applied. The GenReqTypes stereotype is applied to a requirement block by a generalization relationship. When the "Launch By" requirement has the stereotype <<GenReqTypes>>, the attributes of the GenReqTypes are applied. Figure 9 shows selected attributes but more are available. 


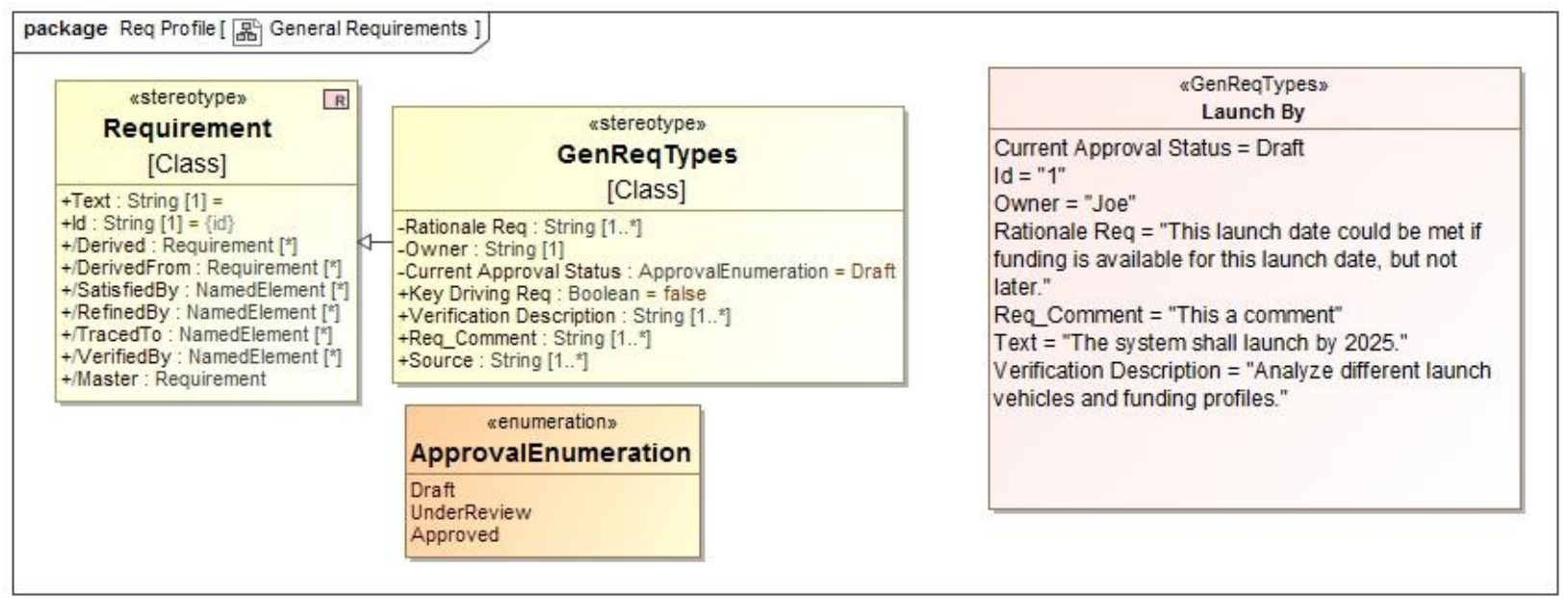

Figure 9. General requirements stereotype profile.

\section{Architecture Definition}

Architecture definition is the system physical and logical structure and interconnections. This is not the WBS structure, but uses a similar construct. The architecture definition defines and breaks down the system into subsystems, and subsystems into assemblies or components, and so on until it is decomposed to the level the project needs. Depending on the project, the architecture may use three levels or less, or may have more levels if necessary. How the system and subsystems interface among each other is described in section XII, Interface Definition. Having the architecture defined can make it easier to identify functions prior to allocating them to subsystems.

\section{A. Artifacts}

The artifact used for architecture definition, in general, are listed Table 20.

Table 20. Architecture definition artifacts.

\begin{tabular}{|l|l|}
\hline Architecture Definition Artifacts & Model Artifact \\
\hline System structure & $\begin{array}{l}\text { Package diagram, block definition diagram or architecture block } \\
\text { definition diagram }\end{array}$ \\
\hline
\end{tabular}

\section{B. Model Elements and Relationships}

The model elements and relationships that are used in architecture definition artifacts are listed in Table 21.

Table 21. Architecture definition model elements and relationships.

\begin{tabular}{|l|l|}
\hline Architecture Definition & Model Element and Relationship \\
\hline System, subsystem, and components & Block. This can be physical or logical structure elements. \\
\hline $\begin{array}{l}\text { Relationships among the system, } \\
\text { subsystem and components }\end{array}$ & Composition relationship. \\
\hline Part of a system & Part property (solid diamond). \\
\hline $\begin{array}{l}\text { Part that contributes to the system } \\
\text { architecture but exists independently }\end{array}$ & Reference property (open diamond). \\
\hline Specific use of a part & $\begin{array}{l}\text { Instantiation of block. This can be for specific choices, such as a model } \\
\text { number or part option. }\end{array}$ \\
\hline
\end{tabular}

\section{Model Validation Information}

Validation is captured in many ways and at various levels of maturity. The main ways to show compliance are described in Table 22. These questions are only a starting point and they can be performed using model-generated tables and diagrams. 
Table 22. Architecture definition validation.

\begin{tabular}{|l|l|}
\hline Validation Question & Validation Method \\
\hline $\begin{array}{l}\text { Does the physical and logical structure decomposition go } \\
\text { down to the correct level? }\end{array}$ & Block definition diagram. \\
\hline $\begin{array}{l}\text { Does the physical and logical structure have the right } \\
\text { components at the right level? }\end{array}$ & Block definition diagram. \\
\hline Does every architectural element perform a function? & Matrix. \\
\hline
\end{tabular}

\section{More Detail}

This structure is used in the allocation of requirements. It is also used in the allocation of functions to architectural elements via activity swim lanes. See section IV, Concept Definition, and section VIII, Requirements and Allocation of Requirements to Next Lower Level.

\section{Required Leading Indicator Trends}

The required leading indicator trends are items such as mass margin, power margin, and the number of actions from reviews. For the trends that can be calculated within the model, go to section V, MOE, MOP and TPM, for more information on performing parametrics (calculation) within the model. This section will only address value properties.

\section{A. Artifacts}

The artifacts used for required leading indicator trends, in general, are listed in Table 23.

Table 23. Required leading indicator artifacts.

\begin{tabular}{|l|l|}
\hline Required Leading Indicator Artifacts & Model Artifact \\
\hline Product leading indicator trends & Simulation results. See section V, MOE, MOP and TPM. \\
\hline
\end{tabular}

\section{B. Model Elements and Relationships}

The model elements and relationships that are used in creating required leading indicator trend artifacts are listed in Table 24.

Table 24. Required leading indicator model elements and relationships.

\begin{tabular}{|l|l|}
\hline Required Leading Indicator & Model Element and Relationship \\
\hline Project Metrics & $\begin{array}{l}\text { Value property within a block. To show trends, an instance is created at } \\
\text { every milestone. These are placed in an instance table to show trends. }\end{array}$ \\
\hline
\end{tabular}

\section{Model Validation Information}

Validation is captured in many ways and at various levels of maturity. The main ways to show compliance are described in Table 25. These questions are only a starting point and they can be performed using model-generated tables and diagrams.

Table 25. Required leading indicator validation.

\begin{tabular}{|l|l|}
\hline Validation Question & Validation Method \\
\hline Are the trends current and up-to-date? & Check the latest instance date that was created and simulated. \\
\hline
\end{tabular}

\section{More Detail}

Another way to get information that is not currently in the model is to use scripts to pull the information and then populate the model from an authoritative source of truth. A set of leading indicators that might exist within a model include: mass, power profile, power margin, number of requirements, number of requirement changes, number of tbd/tbr in requirements, requirements compliance, milestone review artifacts (model related), and verification burndown status. These are leading indicators that could be populated within the model using parametrics (see section $\mathrm{V}, \mathrm{MOE}, \mathrm{MOP}$ and TPM) or by simple scripting techniques. Other, such as review actions status, drawing percent released, number of defects, and schedule slippage would need scripting or manual entry of the information. 
Table 10 shows how the mass roll-up instances can be used for trending. It is easy to follow how the mass of a system changes over time so one can predict whether there would be a risk of failing a metric.

\section{Design Solution Definition}

The design solution definition process is used to generate and evaluate alternative solutions, and select one or more for further work. This process is also known as doing trade studies. Many facets may need to be considered for a comprehensive solution. The alternative solutions artifacts are captured as options in the model, and then the base model is updated based on the decisions. A wide variety of alternative solutions are possible for mission to system to subsystem, etc., so not all of the artifacts are described. Below are just a few to give a feel for what is possible.

\section{A. Artifacts}

The artifacts used for design solution definition, in general, are listed in Table 26.

Table 26. Design solution definition artifacts.

\begin{tabular}{|l|l|}
\hline Design Solution Definition Artifacts & Model Artifact \\
\hline Scenarios of alternative solutions & $\begin{array}{l}\text { Use cases, activity flows. See section IV, Concept Definition, as } \\
\text { alternative solutions are different ways to accomplish a task or mission. }\end{array}$ \\
\hline Effects of alternative solutions & $\begin{array}{l}\text { Instances, parametrics. These are used to collect information for an } \\
\text { alternative solution, such a mass, fuel, or temperature deltas. See section } \\
\text { V, MOP, MOE and TPM. }\end{array}$ \\
\hline $\begin{array}{l}\text { Make-buy-reuse specification } \\
\text { requirements }\end{array}$ & See section XIII, Technical Plans. \\
\hline
\end{tabular}

\section{B. Model Elements and Relationships}

The model elements and relationships are covered in the sections identified in Table 26.

\section{Model Validation Information}

Model validation information is covered in the sections identified in Table 26.

\section{More Detail}

Each of the sections referred to in Table 26 describes the artifacts, model elements and relationships and model validation in more detail.

\section{Interface Definition}

Interface definition describes the interfaces items at each level of the architecture, for example external interfaces at the system level, subsystems to subsystem interfaces at the next level, and continues down to the desired level. This includes both logical and physical interfaces with the associated detail.

\section{A. Artifacts}

The artifacts used for interface definition, in general, are listed in Table 27.

Table 27. Interface definition artifacts.

\begin{tabular}{|l|l|}
\hline Interface Definition Artifacts & Model Artifact \\
\hline Interface diagrams & Interface block diagrams. \\
\hline Interface Control Documents & Tables. \\
\hline
\end{tabular}

\section{B. Model Elements and Relationships}

The model elements and relationships that are used in creating interface definition artifacts are listed in Table 28. 
Table 28. Interface definition model elements and relationships.

\begin{tabular}{|l|l|}
\hline Interface Definition & Model Element and Relationship \\
\hline $\begin{array}{l}\text { System, subsystem, parts, } \\
\text { component }\end{array}$ & $\begin{array}{l}\text { Block. The use of blocks is defined in section IX, Architecture Definition, } \\
\text { and are re-used and elaborated for interface definition. }\end{array}$ \\
\hline Internal system interconnections & Full ports and proxy ports. \\
\hline External system interconnections & Full ports and proxy ports. \\
\hline $\begin{array}{l}\text { Type of matter, data information, or } \\
\text { other entity flowing between } \\
\text { interconnections }\end{array}$ & $\begin{array}{l}\text { Item flows. The item flows can represent power, fluids, or something else } \\
\text { such as mechanical load. }\end{array}$ \\
\hline $\begin{array}{l}\text { Units of what is flowing between } \\
\text { interconnections }\end{array}$ & Value types such as kg, Watts, or bits per second. \\
\hline
\end{tabular}

\section{Model Validation Information}

Validation is captured in many ways and at various levels of maturity. The main ways to show compliance are described in Table 29. These questions are only a starting point and they can be performed using model-generated tables and diagrams.

Table 29. Interface definition validation.

\begin{tabular}{|l|l|}
\hline Validation Question & Validation Method \\
\hline Are all the interfaces are identified? & $\begin{array}{l}\text { The model can help by producing tables and matrixes showing the } \\
\text { relationships between elements. The use of scripts with full ports having } \\
\text { attributes for identifying the interface can be used to validate whether the } \\
\text { system blocks have a least one interface identified. Additional work } \\
\text { would be needed to validate that all the interfaces are correct and that all } \\
\text { interfaces have been identified. }\end{array}$ \\
\hline $\begin{array}{l}\text { Are all the interfaces typed } \\
\text { correctly? }\end{array}$ & Table showing the ports, with item flows typed. \\
\hline $\begin{array}{l}\text { Do the interfaces have the correct } \\
\text { units? }\end{array}$ & Examine the value type for each type of port. \\
\hline
\end{tabular}

\section{More Detail}

The way interfaces are represented is rapidly changing due to modeling tools having more capability to handle the information associated with them. It is important to look at vendor software and identify its capabilities for identifying and validating interfaces.

\section{Technical Plans}

System engineers develop many plans, including Implementation, Verification and Validation, Integration, Operational Plan and Procedure, Decommissioning and Disposal plans. Even though the plans have specific uses, the types of modeling elements utilized are mostly the same. The main differences among them are the content. For this reason, the discussion of these plans is combined in this section. Details associated with these plans, and their functions are captured in NPR 7123.1B. ${ }^{1}$

\section{A. Artifacts}

The artifacts used for technical plans, in general, are listed in Table 30.

Table 30. Technical plan artifacts.

\begin{tabular}{|l|l|l|}
\hline Plan & Artifacts & Model Artifact \\
\hline $\begin{array}{l}\text { Common to all Technical } \\
\text { Plans }\end{array}$ & Plan & $\begin{array}{l}\text { Output from the model using information } \\
\text { from within the model, in addition to } \\
\end{array}$ \\
& & $\begin{array}{l}\text { information that supplements model- } \\
\text { generated content. }\end{array}$ \\
\cline { 2 - 3 } & List of detailed plans or procedures & Table or package diagram. \\
\hline
\end{tabular}




\begin{tabular}{|c|c|c|}
\hline Plan & Artifacts & Model Artifact \\
\hline & $\begin{array}{l}\text { List of Personnel, skill mix and } \\
\text { training }\end{array}$ & Table or matrix. \\
\hline & $\begin{array}{l}\text { Requirements and interfaces for } \\
\text { enabling systems }\end{array}$ & $\begin{array}{l}\text { See section VIII, Requirements and } \\
\text { Allocation of Requirements to Next Lower } \\
\text { Level, and section XII, Interface Definition. }\end{array}$ \\
\hline \multirow[t]{4}{*}{ Implementation Plan } & $\begin{array}{l}\text { Implementation approach for end } \\
\text { product }\end{array}$ & Table or matrix. \\
\hline & $\begin{array}{l}\text { Tools and equipment, raw materials, } \\
\text { and specialized services list }\end{array}$ & Table or matrix. \\
\hline & Vendor list & Table or matrix. \\
\hline & $\begin{array}{l}\text { Constraints from the strategy on the } \\
\text { end product requirements, } \\
\text { architecture, or design }\end{array}$ & Table with constraint blocks listed. \\
\hline \multirow[t]{5}{*}{$\begin{array}{l}\text { Verification and } \\
\text { Validation Plan }\end{array}$} & $\begin{array}{l}\text { Verification approach for each } \\
\text { requirement }\end{array}$ & Table or matrix. \\
\hline & $\begin{array}{l}\text { List of analyses, tests, inspections, } \\
\text { and demonstrations during V\&V }\end{array}$ & Table or verify matrix. \\
\hline & $\begin{array}{l}\text { List of requirements to be verified } \\
\text { with approach }\end{array}$ & Table or verify matrix. \\
\hline & $\begin{array}{l}\text { List of stakeholder expectations to } \\
\text { be validated with approach }\end{array}$ & Table or matrix. \\
\hline & $\begin{array}{l}\text { List of special equipment, } \\
\text { conditions, or procedures }\end{array}$ & Table or matrix. \\
\hline \multirow[t]{3}{*}{ Integration Plan } & $\begin{array}{l}\text { List of integration area or facility, } \\
\text { and storage areas }\end{array}$ & Table or matrix. \\
\hline & $\begin{array}{l}\text { List of test equipment, tooling, and } \\
\text { recording devices }\end{array}$ & Table or matrix. \\
\hline & $\begin{array}{l}\text { List of analyses, tests, inspections, } \\
\text { and demonstrations during } \\
\text { integration }\end{array}$ & Table or matrix. \\
\hline \multirow[t]{3}{*}{$\begin{array}{l}\text { Operational Plan and } \\
\text { Procedure }\end{array}$} & $\begin{array}{l}\text { Operational approaches and } \\
\text { scenarios for nominal operations }\end{array}$ & Activity diagrams, state machine diagrams. \\
\hline & $\begin{array}{l}\text { Operations approaches and } \\
\text { scenarios for contingency, off- } \\
\text { nominal, and degraded operations }\end{array}$ & Activity diagrams, state machine diagrams. \\
\hline & List of operational states and modes & Table or matrix. \\
\hline \multirow{3}{*}{$\begin{array}{l}\text { Decommissioning and } \\
\text { Disposal Plans }\end{array}$} & Approach for end product & Table or matrix. \\
\hline & $\begin{array}{l}\text { Tools and equipment, raw materials, } \\
\text { and specialized services list }\end{array}$ & Table or matrix. \\
\hline & $\begin{array}{l}\text { Constraints from the strategy on the } \\
\text { end product requirements, } \\
\text { architecture, or design }\end{array}$ & Table. \\
\hline
\end{tabular}

\section{B. Model Elements and Relationships}

Most of the model elements and relationships can be shown in a generic table or matrix. The desired content is selected for display. A matrix often shows relationships among different model elements. The model elements and relationships that are used in creating technical plan artifacts are listed in Table 31.

Table 31. Technical plan model elements and relationships.

\begin{tabular}{|l|l|l|}
\hline Plan & Elements & Model Element and Relationship \\
\hline $\begin{array}{l}\text { Common to all } \\
\text { plans }\end{array}$ & Plan & $\begin{array}{l}\text { Package or content diagram. These diagrams contains folders or } \\
\text { package information that can be found elsewhere in the model in a }\end{array}$ \\
\hline
\end{tabular}




\begin{tabular}{|c|c|c|}
\hline Plan & Elements & Model Element and Relationship \\
\hline & & $\begin{array}{l}\text { single diagram. See section VII, Systems Engineering Management } \\
\text { Plan, for more details about these diagrams. }\end{array}$ \\
\hline & Textual content & $\begin{array}{l}\text { Artifact or comment. In the document world, it is the text part of } \\
\text { the document that describes a section. When sections are needed } \\
\text { repeated for other sections, it is better to capture the information in } \\
\text { an artifact for easy reference. Comments and text boxes can be } \\
\text { used, when information is used for a single diagram. The textual } \\
\text { content can be used to generate external document if necessary. }\end{array}$ \\
\hline & $\begin{array}{l}\text { Implementation } \\
\text { approach for end } \\
\text { product }\end{array}$ & $\begin{array}{l}\text { Block from the design solution definition. Each block will have } \\
\text { attributes that specify whether it is acquire new, build new, reuse } \\
\text { without modification, or reuse with modification and any special } \\
\text { considerations. The block multiplicity specifies how many of each } \\
\text { are needed. }\end{array}$ \\
\hline & Detailed procedure & $\begin{array}{l}\text { Use case diagrams, activity diagrams and hyperlinked artifacts or } \\
\text { block to an external procedure. The use case diagram depicts how } \\
\text { an enabling system interacts with the actors to perform the } \\
\text { procedure. The activity diagrams depicts how the procedure will } \\
\text { flow. Many plans and procedures that are developed are kept in an } \\
\text { outside repository and an artifact can be used as a means to } \\
\text { hyperlink the document repository. Artifacts can have attributes } \\
\text { associated with them such as procedural name, date, or author. } \\
\text { However, it is easier to capture this information using a block. }\end{array}$ \\
\hline & $\begin{array}{l}\text { Spares, tools and } \\
\text { equipment, raw } \\
\text { material, or } \\
\text { specialized service }\end{array}$ & $\begin{array}{l}\text { Block. The details of these can be captured in value property } \\
\text { attributes. The blocks can have allocation relationships with } \\
\text { activities and end products. }\end{array}$ \\
\hline & $\begin{array}{l}\text { Vendor and } \\
\text { Personnel }\end{array}$ & $\begin{array}{l}\text { Actor and block. Each vendor or person can be depicted as an actor, } \\
\text { which can be refined by a block. }\end{array}$ \\
\hline & Skills and training & $\begin{array}{l}\text { Block, but also be used as a part property for personnel block doing } \\
\text { product implementation }\end{array}$ \\
\hline & $\begin{array}{l}\text { Requirement for } \\
\text { enabling systems }\end{array}$ & $\begin{array}{l}\text { See section VIII, Requirements and Allocation of Requirements to } \\
\text { Next Lower Level. }\end{array}$ \\
\hline & $\begin{array}{l}\text { Interface for } \\
\text { enabling systems }\end{array}$ & See section XII, Interface Definition. \\
\hline & Constraints & $\begin{array}{l}\text { Constraint blocks. These blocks are used to perform analysis such } \\
\text { as validating that a requirement can still be met due to the } \\
\text { implementation strategy on the end product requirements, } \\
\text { architecture, or design. See section V, MOE, MOP and TPM. }\end{array}$ \\
\hline & $\begin{array}{l}\text { Integration area or } \\
\text { facility, and storage } \\
\text { areas }\end{array}$ & Block. \\
\hline & $\begin{array}{l}\text { Analyses, tests, } \\
\text { inspections, and } \\
\text { demonstrations } \\
\text { during integration }\end{array}$ & TestCase activity. \\
\hline & $\begin{array}{l}\text { Operational states } \\
\text { and modes }\end{array}$ & State machines and state machine diagrams. \\
\hline $\begin{array}{l}\text { Verification and } \\
\text { Validation Plan }\end{array}$ & $\begin{array}{l}\text { Requirements to be } \\
\text { verified }\end{array}$ & $\begin{array}{l}\text { See section VIII, Requirements and Allocation of Requirements to } \\
\text { Next Lower Level, and section XII, Interface Definition. Each } \\
\text { requirement has a relationship with one or more verification events. } \\
\text { A Verify matrix shows the relationships between requirements and } \\
\text { the verification events. }\end{array}$ \\
\hline
\end{tabular}




\begin{tabular}{|l|l|l|}
\hline Plan & Elements & Model Element and Relationship \\
\hline & $\begin{array}{l}\text { Stakeholder } \\
\text { expectations to be } \\
\text { validated }\end{array}$ & $\begin{array}{l}\text { See section III, Stakeholder Identification and Expectations } \\
\text { Definition. Each expectation that is to be validated has a } \\
\text { relationship with one or more validation events. }\end{array}$ \\
\cline { 2 - 3 } $\begin{array}{l}\text { Verification } \\
\text { approach or method } \\
\text { for each requirement }\end{array}$ & $\begin{array}{l}\text { Value property of a requirement block named VerifyMethod. The } \\
\text { property has an enumerated value type such as } \\
\text { VerificationMethodKind. The allowed enumerated value types are } \\
\text { user defined, and typically are analysis, test, demonstration, } \\
\text { inspection, roll-up, synthesis, or combinations. }\end{array}$ \\
\cline { 2 - 3 } & \begin{tabular}{l} 
Verification or \\
validation event \\
\cline { 2 - 3 }
\end{tabular} & $\begin{array}{l}\text { Activity with the stereotype <<testcase>>. Each event can be } \\
\text { represented as a <<test case>>that is related to the requirement } \\
\text { block through a verify relationship. The different test cases can be } \\
\text { depicted on a requirement diagram showing the details of the test } \\
\text { cases within a particular test procedure. }\end{array}$ \\
\hline
\end{tabular}

\section{Model Validation Information}

Validation is captured in many ways and at various levels of maturity. The main ways to show compliance are described in Table 32. These questions are only a starting point. The validation method for the question can be performed using model-generated tables, matrices and diagrams; the details are not captured.

Table 32. Technical plan validation.

\begin{tabular}{|l|l|}
\hline Plan & Validation Question \\
\hline \multirow{4}{*}{ Common to all plans } & Do all plans and procedures have an owner and status? \\
\cline { 2 - 2 } & $\begin{array}{l}\text { Do all completed plans and procedures have a hyperlink to an external location } \\
\text { or links to table and diagrams within the model? }\end{array}$ \\
\cline { 2 - 2 } & Does each end product have an approach, plan, procedure or sequence? \\
\cline { 2 - 2 } & Does each end product have a responsible organization? \\
\cline { 2 - 2 } & Are specialized skills, tools, and training identified? \\
\hline Implementation Plan & Are requirements and interfaces to enabling systems identified? \\
\hline \multirow{5}{*}{ Plan } & Do all requirements have a verification approach? \\
\cline { 2 - 2 } & Do all analyses, tests, inspections, and demonstrations have an owner? \\
\cline { 2 - 2 } & Are V\&V areas, test equipment, tools, and training identified? \\
\cline { 2 - 2 } & $\begin{array}{l}\text { Does each verification indicate when it is necessary to be completed, such as } \\
\text { prior to system integration or product transition? }\end{array}$ \\
\hline Integration Plan & Are integration areas, test equipment, tools, and training identified? \\
\cline { 2 - 2 } & $\begin{array}{l}\text { Are analyses, tests, inspections, and demonstrations occurring during integration } \\
\text { identified? }\end{array}$ \\
\hline Operational Plan & Are contingency, off-nominal, and degraded operation scenarios addressed? \\
\cline { 2 - 2 } & Have the operational states and modes been identified? \\
\hline Operational Procedure & $\begin{array}{l}\text { Have contingency, off-nominal, and degraded operation scenarios been } \\
\text { developed? }\end{array}$ \\
\hline Decommission Plan & Have decommission of product being included into the design of the mission? \\
\hline Disposal Plan & Are specialized skills, tools, and training identified? \\
\cline { 2 - 2 } & Are requirements and interfaces to enabling systems identified? \\
\hline
\end{tabular}

\section{Verification and Validation Results}

The results from verification and validation $(\mathrm{V} \& \mathrm{~V})$ include the outcomes of product verification and validation and reports providing the evidence of conformance with the requirements or expectations. V\&V results also include work products such as records of procedural steps, failures or anomalies, corrective actions, and waivers.

\section{A. Artifacts}

The artifacts used for verification and validation results, in general, are listed in Table 33. 
Table 33. V\&V artifacts.

\begin{tabular}{|l|l|}
\hline Verification and Validation Artifacts & Model Artifact \\
\hline Verification report for each specified requirement & Table or requirement diagram. \\
\hline $\begin{array}{l}\text { Verification and validation event metrics (number } \\
\text { complete, number remaining) }\end{array}$ & Parametric results. \\
\hline $\begin{array}{l}\text { Requirement metrics (number verified, number } \\
\text { remaining) }\end{array}$ & Parametric results. \\
\hline $\begin{array}{l}\text { Expectation metrics (number validated, number } \\
\text { remaining) }\end{array}$ & Parametric results. \\
\hline $\begin{array}{l}\text { List of results for each verification and validation } \\
\text { event }\end{array}$ & Table or matrix. \\
\hline List of external reports & Table or matrix with hyperlinks. \\
\hline $\begin{array}{l}\text { List of verification events and as-performed } \\
\text { procedures }\end{array}$ & Table or matrix. \\
\hline List of failures, anomalies, and corrective actions & Table or matrix of events that meet this criteria. \\
\hline List of waivers & Table or matrix of requirements that meet this criteria. \\
\hline
\end{tabular}

\section{B. Model Elements and Relationships}

The following model elements and relationships are often found in a verification report and can be represented by model elements and relationships as listed in Table 34.

Table 34. V\&V model elements and relationships.

\begin{tabular}{|l|l|}
\hline Verification and Validation & Model Element and Relationship \\
\hline Requirement & $\begin{array}{l}\text { See section VIII, Requirements and Allocation of Requirements } \\
\text { to Next Lower Level. }\end{array}$ \\
\hline Requirement traceability & $\begin{array}{l}\text { See section VIII, Requirements and Allocation of Requirements } \\
\text { to Next Lower Level. }\end{array}$ \\
\hline Verification method & $\begin{array}{l}\text { See section VIII, Requirements and Allocation of Requirements } \\
\text { to Next Lower Level, and section XIII, Technical Plans. }\end{array}$ \\
\hline Special equipment, conditions, or procedures & $\begin{array}{l}\text { See section VIII, Requirements and Allocation of Requirements } \\
\text { to Next Lower Level, and section XIII, Technical Plans. }\end{array}$ \\
\hline Result or status of each verification event & $\begin{array}{l}\text { Output activity parameter for a Test Case, with user-defined } \\
\text { name such as verdict. The parameter would have an enumerated } \\
\text { value type with user-defined name such as VerdictKind that can } \\
\text { have legal values such as Not Started, In Work, Pass, Fail, etc. }\end{array}$ \\
\hline $\begin{array}{l}\text { Existence of a variation, anomaly, or out-of- } \\
\text { compliance result }\end{array}$ & $\begin{array}{l}\text { Output activity parameter for a Test Case, with user-defined } \\
\text { name such as variation, anomaly, or out-of-compliance. The } \\
\text { parameter would have a value type of Boolean (false or true). }\end{array}$ \\
\hline $\begin{array}{l}\text { Variation, anomaly, or out-of-compliance } \\
\text { result }\end{array}$ & $\begin{array}{l}\text { Block that has the appropriate information. The block is a } \\
\text { reference property of the requirement block and has a hyperlink } \\
\text { to external information. }\end{array}$ \\
\hline $\begin{array}{l}\text { Corrective action and result of corrective } \\
\text { action }\end{array}$ & $\begin{array}{l}\text { Each action or result is represented as a block that contains } \\
\text { attributes such as the owner. The block has a relationship to the } \\
\text { test case and has a hyperlink to the external corrective action or } \\
\text { result. }\end{array}$ \\
\hline Verification or validation status & $\begin{array}{l}\text { Attribute of a requirement block. A parametric diagram can be } \\
\text { used to calculate metrics such as adding up the total number of } \\
\text { requirements, the number of requirements verified, and the } \\
\text { number remaining. }\end{array}$ \\
\hline External Report & $\begin{array}{l}\text { Block that contains attributes such as report name and report } \\
\text { owner. The block has a relationship to the requirement block } \\
\text { and has a hyperlink to external information. }\end{array}$ \\
\hline
\end{tabular}




\begin{tabular}{|l|l|}
\hline Verification and Validation & Model Element and Relationship \\
\hline Record of procedural steps & $\begin{array}{l}\text { Block that contains attributes such as as-run procedure name } \\
\text { and owner. The block has a relationship to the test case and has } \\
\text { a hyperlink to the completed as-run procedure. }\end{array}$ \\
\hline Waiver & Block that contains attributes such as the owner. \\
\hline
\end{tabular}

\section{Model Validation}

Validation is captured in many ways and at various level of maturity. The main ways to show compliance are described in Table 35. These questions are only a starting point and they can be performed using model-generated tables and diagrams.

\section{Table 35. V\&V validation.}

\begin{tabular}{|l|l|}
\hline Validation Question & Validation Method \\
\hline Does each TestCase have a status or result? & Table. \\
\hline $\begin{array}{l}\text { Does each requirement have a verification or } \\
\text { validation status? }\end{array}$ & $\begin{array}{l}\text { Table showing that the verification report has been } \\
\text { approved. }\end{array}$ \\
\hline
\end{tabular}

\section{More Detail}

The Expanded Guidance Document Volume 1, Section $5.3^{2}$ contains additional information on performing product verification and Section 5.4 for additional information on performing product validation.

Figure 10 shows a verification requirement (Id and Name) that is similar to requirements, but has specific attributes such as verification status. The figure also shows the requirement (Requirement Id \& Name) that the verification requirement closes.

\begin{tabular}{|c|c|c|c|c|}
\hline \multicolumn{2}{|c|}{ Element Type: } & GenVerificationReq & Scope (optional): & : Drag elements from the Mode \\
\hline \# & $\Delta$ Id & Name & $\begin{array}{l}\text { Verification_- } \\
\text { Status }\end{array}$ & Requirement Id \& Name \\
\hline 1 & 401 & 目 Launch By Verification & Closed & 目 Launch By \\
\hline 2 & 402 & 目 Lifetime Verification & In_Process & \\
\hline 3 & 403 & E Environment Verification & Completed & R 3 Environment \\
\hline 4 & 404 & 目 Development technology Verification & Open & \\
\hline 5 & 405 & 目 Operate Verification & Open & \\
\hline 6 & 405.1 & 目 Orbit autonomously Verification & Open & \\
\hline 7 & 405.2 & 目 Orbit maintenance Verification & Open & \\
\hline
\end{tabular}

Figure 10. Verification status information diagram.

\section{Transportation criteria and instructions}

The criteria for transportation can be stated as the requirements for transporting a product during manufacturing, assembly, integration, test and evaluation, or delivery to the customer. Requirements for packaging, special containers, handling equipment and fixtures, storage facilities, and transportation facilities fall in this category. Sensitive or hazardous products may have additional requirements to cover safety and environmental conditions during storage and transportation.

The aspects of transportation that cover the tracking of the configuration of the product, along with the data package, are not covered here. Those are typically handled by configuration and data management analysts.

Transportation instructions may be for procedures or other tasks associated with the handling and storage of a product.

\section{A. Artifacts}

The artifacts used for transportation criteria and instructions, in general, are listed in Table 36. 
Table 36. Transportation artifacts.

\begin{tabular}{|l|l|}
\hline Transportation Artifacts & Model Artifact \\
\hline List of transportation criteria & Table or matrix. \\
\hline Transportation approach & Activity diagram. \\
\hline List of transportation instructions & Table or matrix. \\
\hline
\end{tabular}

\section{B. Model Elements and Relationships}

The model elements and relationships that are used in creating transportation artifacts are listed in Table 37.

Table 37. Transportation model elements and relationships.

\begin{tabular}{|l|l|}
\hline Transportation & Model Element and Relationship \\
\hline Transportation requirement & $\begin{array}{l}\text { See section VIII, Requirements and Allocation of Requirements to Next } \\
\text { Lower Level. }\end{array}$ \\
\hline Transportation Personnel & $\begin{array}{l}\text { Actor and block. Each person can be depicted as an actor, which can be } \\
\text { refined by a block. The actor may be used in use case or activity } \\
\text { diagrams. Initially the actor and the block would be named by the role, } \\
\text { such as crane operator, forklift operator, bonded storage custodian, etc. } \\
\text { The block could contain part properties such as required skills and } \\
\text { training. Later, the block would have value properties such as responsible } \\
\text { organization, address, name or point of contact, or contact information. } \\
\text { The block can have an allocation relationship with the end product(s), } \\
\text { activities, test cases, or transportation instructions. }\end{array}$ \\
\hline Skills and training list & $\begin{array}{l}\text { Block. A skill or training can be depicted as a block, and used as a part } \\
\text { property for personnel doing product transportation. }\end{array}$ \\
\hline $\begin{array}{l}\text { Special containers, handling } \\
\text { equipment and fixtures, storage } \\
\text { facilities, and transportation facilities }\end{array}$ & $\begin{array}{l}\text { Block. A container, handling equipment or fixture, facility, or specialized } \\
\text { service is represented as a block. The blocks can have value properties, } \\
\text { such as type of fixture, or calibration or certification status. The blocks } \\
\text { can have allocation relationships with activities and end products. These } \\
\text { also can be modelled as a unique component subsystem or system } \\
\text { themselves with their own requirements and verification depending on } \\
\text { the complexity. }\end{array}$ \\
\hline Transportation instructions & $\begin{array}{l}\text { Use case diagram, activity diagram. The details of a particular instruction } \\
\text { or procedure can be presented in a use case diagram, or an activity } \\
\text { diagram or series of diagrams. The use case diagram depicts how an } \\
\text { enabling system such as containers, fixtures, facilities, and services will } \\
\text { be used by transportation personnel to transport the end products. The } \\
\text { activities are the steps for that part of the transportation, and can have } \\
\text { multiple levels of increasing detail. The activities can be allocated to } \\
\text { actors or blocks. }\end{array}$ \\
\hline
\end{tabular}

\section{Model Validation Information}

Validation is captured in many ways and at various level of maturity. The main ways to show compliance are described in Table 38. These questions are only a starting point and they can be performed using model-generated tables and diagrams.

Table 38. Transportation validation.

\begin{tabular}{|l|l|}
\hline Validation Question & Validation Method \\
\hline $\begin{array}{l}\text { Does each end product undergoing transportation have } \\
\text { a responsible person allocated to perform } \\
\text { transportation? }\end{array}$ & Table showing the responsible person. \\
\hline
\end{tabular}




\begin{tabular}{|l|l|}
\hline Validation Question & Validation Method \\
\hline $\begin{array}{l}\text { If the end product is sensitive or hazardous, do } \\
\text { requirements for safe handling during transportation } \\
\text { exist? }\end{array}$ & $\begin{array}{l}\text { Satisfy matrix showing that requirements were } \\
\text { developed. }\end{array}$ \\
\hline Are special skills, equipment, and facilities identified? & Table showing all the transportation attributes. \\
\hline
\end{tabular}

\section{More Detail}

See the Expanded Guidance Document Volume 1, Section $5.5,{ }^{2}$ for additional information on performing transportation.

\section{Certification (flight/use)}

Certification for flight or use occurs with the submission of a data package that includes verification results, reports, and other evidence to indicate the design is certified. An example of the data package for flight is a Human Rating Certification Package. An example of the data package for use is a critical lift hardware certification package.

\section{A. Artifacts}

The artifacts used to identify certification, in general, are listed in Table 39.

\section{Table 39. Certification artifacts.}

\begin{tabular}{|l|l|}
\hline Certification Artifacts & Model Artifact \\
\hline Certification criteria or deliverables & Table, matrix. \\
\hline Certification data package & Package diagram. \\
\hline $\begin{array}{l}\text { Evidence of compliance to } \\
\text { certification criteria }\end{array}$ & Matrix, requirements diagram. \\
\hline
\end{tabular}

\section{B. Model Elements and Relationships}

The model elements and relationships that are used in creating certification artifacts are listed in Table 40.

Table 40. Certification model elements and relationships.

\begin{tabular}{|l|l|}
\hline Certification & Model Element and Relationship \\
\hline Certification criteria & $\begin{array}{l}\text { Requirement. The criteria or deliverables are modeled as requirements. } \\
\text { See section VIII, Requirements and Allocation of Requirements to Next } \\
\text { Lower Level. }\end{array}$ \\
\hline Verification result & See section XIV, Verification and Validation Results. \\
\hline Report & See section XIV, Verification and Validation Results. \\
\hline Waiver & See section XIV, Verification and Validation Results. \\
\hline
\end{tabular}

\section{Model Validation Information}

Validation is captured in many ways and at various level of maturity. The main ways to show compliance are described in Table 41. These questions are only a starting point and they can be performed using model-generated tables and diagrams.

Table 41. Certification validation.

\begin{tabular}{|l|l|}
\hline Validation Question & Validation Method \\
\hline $\begin{array}{l}\text { Are all the certification criteria and deliverables in the } \\
\text { model? }\end{array}$ & Table. \\
\hline $\begin{array}{l}\text { Do all the certification criteria and deliverables have a } \\
\text { satisfy relationship with the correct evidence? }\end{array}$ & Matrices. \\
\hline
\end{tabular}




\section{Conclusion}

The gap between learning MBSE and the application of those skills within a project is often significant. The information and examples in this paper are intended to increase the use of MBSE by assisting those who are trained in tools and languages to use their knowledge more effectively. These approaches are useful to systems engineers and also to project managers, review board members, and other key project stakeholders.

Systems engineering is used throughout the project lifecycle and in many types of projects. A SysML system model can contain or generate most systems engineering products to a significant extent. Describing the use of MBSE for all the products and tasks encountered in a project is beyond what can be covered in this paper, so the work presented here is limited to the required and primary products for project life-cycle and technical reviews. The use of MBSE can reduce the schedule impact usually experienced for review preparation, as in many cases the review products can be auto-generated directly from the system model. Future work could provide more complete coverage of the topic.

\section{References}

${ }^{1}$ National Aeronautics and Space Administration, 2015, NASA Procedural Requirements 7123.1B w/ Ch3, "NASA Systems Engineering Processes and Requirements," NASA Office of the Chief Engineer. Washington, DC (US).

${ }^{2}$ National Aeronautics and Space Administration, 2016, "Expanded Guidance for NASA Systems Engineering. Volume 1: Systems Engineering Practices," NASA Office of the Chief Engineer. Washington, DC (US).

${ }^{3}$ National Aeronautics and Space Administration, 2016, "Expanded Guidance for NASA Systems Engineering. Volume 2: Crosscutting Topics, Special topics, and Appendices," NASA Office of the Chief Engineer. Washington, DC (US).

${ }^{4}$ Object Management Group, 2015, "OMG Systems Modeling Language (OMG SysML ${ }^{\mathrm{TM}}$ ) Version 1.4." Needham, MA (US).

${ }^{5}$ Weiland, Karen J. and Holladay, Jon, 2017, "Model-Based Systems Engineering Pathfinder: Informing the Next Steps," 27th Annual INCOSE International Symposium (IS 2017). Adelaide, Australia, July 15-20, 2017.

${ }^{6}$ National Aeronautics and Space Administration, 2010, NASA/SP-2010-3404, "Work Breakdown Structure (WBS) Handbook," NASA Office of the Chief Engineer. Washington, DC (US). 